\title{
Hydrologic Effects of
}

Water Spreading in

\section{Box Creek Basin}

Wyoming

GEOLOGICAL SURVEY WATER-SUPPLY PAPER 1532-A

Prepared in cooperation with the U.S. Bureau of Reclamation

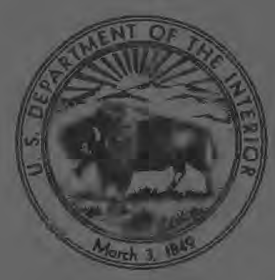




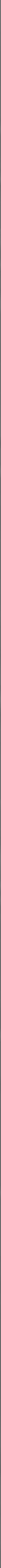




\section{Hydrologic Effects of}

Water Spreading in

\section{Box Creek Basin}

\section{Wyoming}

By R. F. HADLEY, I. S. McQUEEN, and others

HYDROLOGIC EFFECTS OF LAND USE

GEOLOGICAL SURVEY WATER-SUPPLY PAPER 1532-A

Prepared in cooperation with

the U.S. Bureau of Reclamation

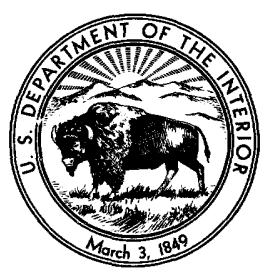




\section{UNITED STATES DEPARTMENT OF THE INTERIOR}

STEWART L. UDALL, Secretary

\section{GEOLOGIGAL SURVEY}

Thomas B. Nolan, Director Washington 25, D.C. 


\section{CONTEN'TS}

Abstract

Introduction

Purpose and scope of study ......... A-1

Acknowledgments . .

Location and general features ......... A-4

Description of the water-spreading system .

Procedures and instrumentation

Precipitation measurements....... A-5

Runoff measurements ... . . . . . . . . . . . . . . . . . . . . A

Observation wells_... A-7

Sedimentation measurements

Infiltration tests..... A-9

Soil-moisture observations

Analysis of precipitation data

Runoff data.... A-14

Box Creek near Bill

Box Creek at mouth . . . .

Disposition of streamflow on the water spreader ...... A-17

Computations based on streamflow records . . . . . . . . . . . A-17

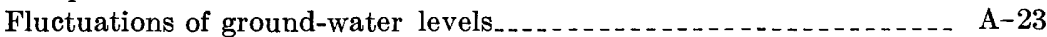

Fluctuations in soil-moisture content and their interpretation....... A-24

Soil-moisture retention relationships _. _......... A-27

Significance of moisture-retention limits . . . . . _ _ _ . . . _ A-29

Moisture-retention data . .

Estimation of moisture absorption

Moisture use

Interpretation of sediment measurements...

Sedimentation ranges . . . . . . . . . . .

Suspended-sediment measurements.

Conclusions...... A-38

Records . . .

Runoff into observation reservoirs . . . . . . . . . . . . . . . . A-39

Soil-moisture observations

References cited._.

Index 


\section{ILLUSTRATIONS}

Figure 1. Map of part of Box Creek basin

2. Two views of the valley of Box Creek showing typical dikes.-

3. Map and profile of Box Creek water spreader..........

4. Double-mass curve comparing seasonal precipitation at Bill $14 \mathrm{SE}$, with that at Douglas and Dull Center. .........

5. Frequency curves of seasonal precipitation at Dull Center

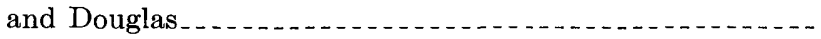

6. Frequency curves of annual maximum daily precipitation at Dull Center and Douglas................................

7. Map of part of Box Creek basin showing average runoff for

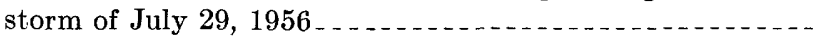

8. Map of part of Box Creek basin showing average runoff for

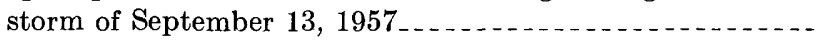

9. Flood hydrographs for gaging stations at Box Creek for the period June 9-14, 1957.

10. Flood hydrographs for gaging stations at Box Creek for the period June 30 to July 4, 1957

11. Graph showing land surface and water level in Box Creek water-spreading area, July 10, 1957.

12. Hydrographs of five observation wells in the Box Creek water-spreading area, 1957 .

13. Graphs showing soil-moisture content in the Box Creek water-spreading area at 12-inch sampling depth during the summer seasons 1956-57.

14. Moisture-retention curves for sampling site M3

15. Sedimentation ranges in the Box Creek basin

16. Histograms of suspended-sediment load at gaging stations on Box Creek, June 9-14, 1957

17. Histograms of suspended-sediment load at gaging stations on Box Creek, June 30 to July 4, 1957.

A-35

\section{TABLES}

TABLE 1. Precipitation in Box Creek area for periods July 11 to September 21, 1956, and May 16 to September 13, 1957......

2. Infiltration rates from ring infiltrometer tests ............

3. Disposition of streamflow in Box Creek during selected periods, 1956-57

4. Soil-moisture retention data for samples from Box Creek

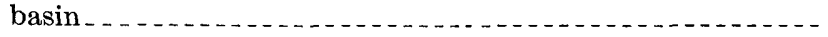

5. Sedimentation on Box Creek water spreader from July 2, 1956, to November 13, $1957 \ldots$ 


\title{
HYDROLOGIC EFFEGTS OF WATER SPREADING IN BOX GREEK BASIN, WYOMING
}

\author{
By R. F. Hadley, I. S. McQueen, and others
}

\begin{abstract}
A study was made during the summer seasons of 1956 and 1957 to determine the use of water by a water-spreading system in Box Creek basin, Converse County, Wyo., which was designed to reduce sediment yield and fluvial erosion. The water-spreading system on Box Creek consists of 27 small dams that divert the flow directly onto the flood plain, where it is used to irrigate a hay meadow of 360 acres.

Two gaging stations were established, one above the water-spreading system and one below, to measure inflow, outflow, and suspended sediment. Also, a network of precipitation gages, ground-water observation wells, and observations on soil-moisture were an integral part of the hydrologic investigation.

There were six runoff events during the 1956 and 1957 seasons for which inflow and outflow through the water-spreading system could be determined. The total inflow for the six runoff periods was 2,026 acre-feet and the outflow was 1,330 acre-feet, which represents a loss of 34 percent of surface flow entering the water spreader.

Total reduction in suspended-sediment load for the six runoff periods was not determined because of the many ungaged tributaries between gaging stations. However, two of the storms originated above the upper gaging station and the suspended-sediment load in the inflow was 4,513 tons and the outflow was 1,119 tons, which represents a decrease of 75 percent between stations. During the 2 years of observation, the total sediment deposition on the water-spreading system was 17.8 acre-feet or 0.049 acre-foot per acre. Most of this sediment was derived from slopes adjacent to the water spreader and, therefore, introduced some uncertainties in evaluating the sediment-retention efficiency of this type of land treatment.

Data from ground-water observation wells show that some of the surface flow entering the water-spreading system at the upper end may penetrate to a perched water table.
\end{abstract}

\section{INTRODUCTION}

\section{PURPOSE AND SCOPE OF STUDY}

This report presents the results of a study that was begun in July 1956 to determine the effect on streamflow and sedimentation of a particular type of land treatment. This and two other studies (Culler, 1961; Hadley and Schumm, 1961) are concerned with the problem of reducing the contribution of sediment to Angostura 
Reservoir on the Cheyenne River and the effect on streamflow of measures designed to reduce sediment transport.

The treatment practice used on Box Creek represents a type that might be used in several other areas with the prospect of reducing appreciably the movement of sediment to Angostura Reservoir. The study area is located in a part of the valley of Box Creek owned by Jack Downs, whose ranch extends from near the mouth of Box Creek upstream for about 5 miles. (See fig. 1.)

Land treatment within the area includes several diversion dams and dikes designed primarily to spread flood flows across the valley floor or flood plain of Box Creek, thereby furnishing flood irrigation on a hay meadow and preventing concentration of flow in the channels.

As a result of the streamflow diversions and water spreading, a substantial part of the sediment carried into the reach is believed to have been trapped and deposited on the valley floor. Also, it may be assumed that streamflow entering the water spreader is depleted in some degree by infiltration on the valley floor. The specific objective of this study was to obtain quantitative data on the disposition of both streamflow and sediment.

The studies were made in Box Creek basin in Converse County, Wyo., under a cooperative agreement with the U.S. Bureau of Reclamation. Field observations in the water-spreading system were made by the U.S. Geological Survey under the general supervision of C. C. McDonald, chief, General Hydrology Branch. The fieldwork was under the immediate supervision of $K$. R. Melin, project hydrologist. The data were analyzed and the report was prepared by R. F. Hadley and I. S. McQueen with the assistance of R. W. Lichty, G. C. Lusby, and C. T. Sumsion. Resident observer in the study area during the 1956 season was L. W. Greene and during the 1957 season was R. W. Lichty.

Streamflow records for the gaging station, Box Creek near Bill, Wyo., which were used in computing inflow to the water spreader, were obtained by the Surface Water Branch under the immediate supervision of the late J. M. Terry, district engineer, Denver, Colo. Analyses of suspended-sediment samples were made by the Quality of Water Branch under the immediate supervision of T. F. Hanly, district engineer, Worland, Wyo.

\section{ACKNOWLEDGIMENTS}

The writers wish to express their appreciation to Whitney M. Borland, Carl R. Miller, and John R. Sheppard of the U.S. Bureau of Reclamation for their helpful suggestions and assistance during the course of the study. Also, the cooperation of Jack Downs and Lee Moore, ranchers in the area, in granting permission to do the 


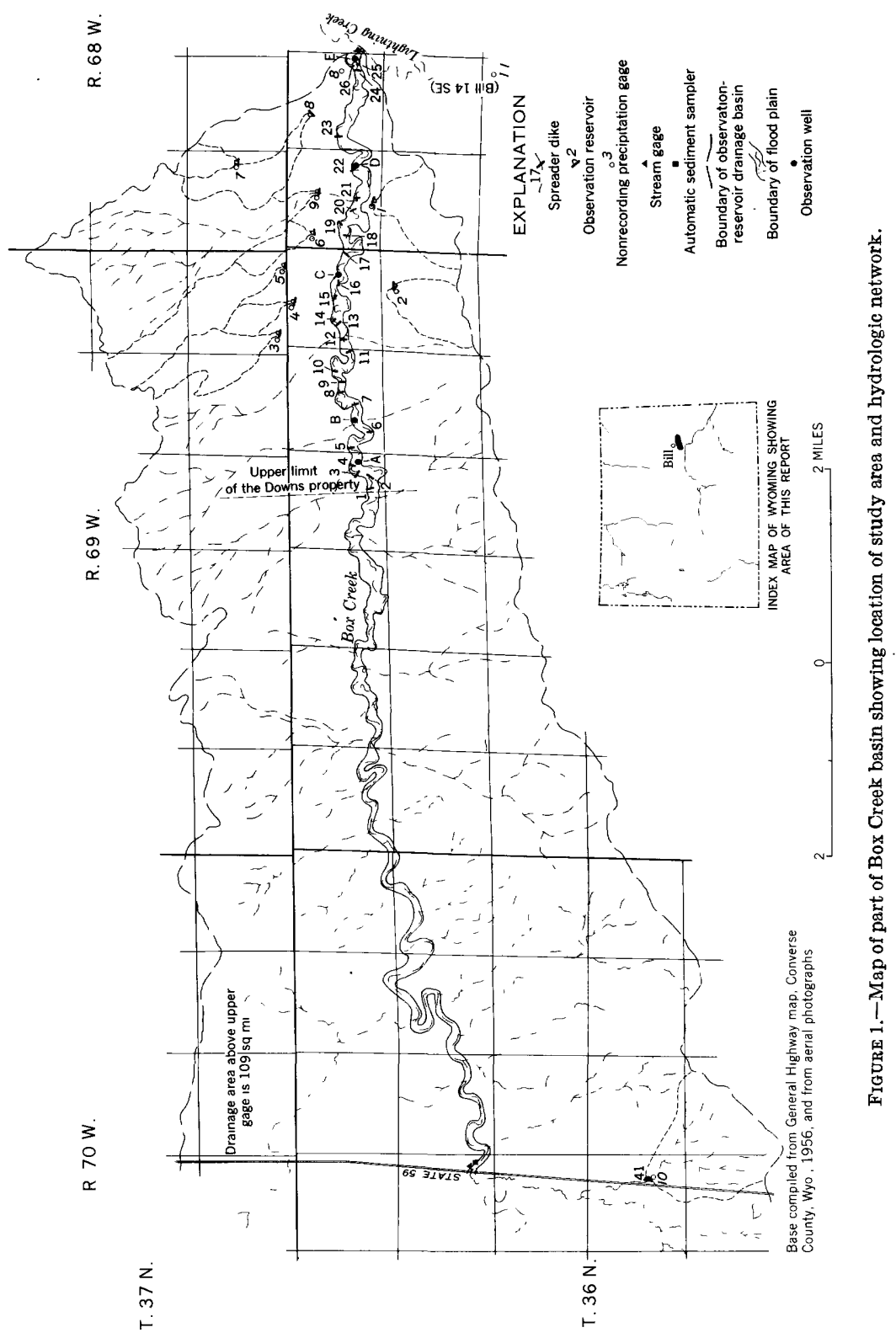


study on their lands and in providing assistance to the resident observers is gratefully acknowledged.

\section{LOCATION AND GENERAL FEATURES}

Box Creek is tributary to Lightning Creek, which in turn flows into Lance Creek, a stream draining about 2,000 square miles in the southwestern part of the Cheyenne River basin above Angostura Reservoir. The drainage area of Box Creek is about 158 square miles of which an area of 140 square miles is upstream from the water spreader.

The drainage basin of Box Creek may be divided into two provinces on the basis of topography and geology. The upper two-thirds of the basin is gently rolling and relatively undissected, with relief less than 100 feet. The density of vegetation is generally good to excellent and erosion both on upland slopes and in channels in slight. This part of the basin is underlain by the Wasatch formation of Eocene age, which is composed of sandstone and sandy shale.

In the lower one-third of the basin, or that part downstream from or east of Wyoming State Route 59 (fig. 1), the terrain becomes steeper and more dissected by tributary channels and gullies that drain the valley sides. The geology is also markedly different. The underlying bedrock is composed of interbedded sandstone and shale, with shale predominant, and belongs to the Fort Union formation of Paleocene age. The flood plain along the lower reaches of Box Creek ranges in width from about 500 to 1,500 feet and is underlain by fine-grained alluvium. The density of vegetation on the flood plain and colluvial slopes is generally good, but the steep breaks along the divides bear a sparse growth of vegetation and are severely eroded. The breaks probably furnish much of the sediment and runoff to the water-spreader area. The water spreader, which occupies the flood plain of Box Creek for a distance of $4 \frac{1}{2}$ miles upsteam from the mouth of the creek, has an average width of 400 feet and covers about 360 acres.

\section{DESCRIPTION OF THE WATER-SPREADING SYSTEM}

The Box Creek water spreader differs from most water spreaders, as commonly constructed, in that no contour dikes are provided to direct the diverted flow. According to Mr. Downs and other longtime residents of the area, the channel of Box Creek was once a sizable gully. Sometime before 1930 an attempt was made to control the erosion of the gully by felling cottonwood trees into it. These trees constituted a barrier to flood flows and caused some deposition of sediment in the channel. When the gully had been filled enough to work in, with the equipment available at that time, small diversion 
dikes were constructed (fig. 2). The dikes induce sediment deposition in the gully and divert the flow for irrigation of the flood plain. The system of dikes has been expanded and improved through the years until, in 1957, the entire flood plain was being irrigated by diversions brought about by 27 dikes. However, the fact that the flood plain of Box Creek is very regular and has a low gradient (0.45 percent), undoubtedly, accounts to some degree for the success of the treatment and also for the general absence of scouring and trenching of the flood plain that occur in other localities where conditions are less favorable.

The growth of vegetation, which has been improved progressively, undoubtedly has induced deposition of sediment and also may have increased infiltration to an appreciable extent. The vegetation produced on the water spreader is of great economic importance to the ranching operation in the valley. In most years, the irrigated flood plain produces two cuttings of hay and winter pasturage for cattle.

\section{PROCEDURES AND INSTRUMENTATION}

To measure precipitation, runoff, and sediment and to obtain data on the disposition of water and sediment on the spreading area, a network of rain gages, stream gages, erosion and depositional ranges, and other observations were established in the Box Creek basin. (See fig. 1.)

In this report seasonal values for amounts of precipitation, runoff, and suspended-sediment are used instead of annual totals in all computations. The season, or part of year used, is the 6-month period April through September. In the streamflow data for the two gaging stations shown on pages $\mathrm{A}-15$ and $\mathrm{A}-16$, records for October 1956 and 1957 are given because observations continued through that month. The suspended-sediment data on pages A-36 and A-37 are for the 1957 season only.

\section{PRECIPITATION MEASUREMENTS}

For the measurement of precipitation, 6 gages were operated. during the 1956 season and 11 in 1957. Two were standard nonrecording rain gages, of which one (No. 8) was located at the Downs ranch near the mouth of Box Creek, the other (No. 11) was located at the Lee Moore ranch, 1 mile west of the confluence of Box Creek and Lightning Creek. The latter gage is a regular U.S. Weather Bureau gage designated Bill $14 \mathrm{SE}$, and daily precipitation records for the period 1949-57 are published by the U.S. Weather Bureau (1949-57). All other gages used were oil cans placed at various localities within the study area. Evaporation loss was minimized by maintaining a film of oil on the water surface and by checking the accumulation of rain as soon as possible after every storm.

$6027150-61-2$ 


\section{A-6 HYDROLOGIC EFFECTS OF LAND USE}
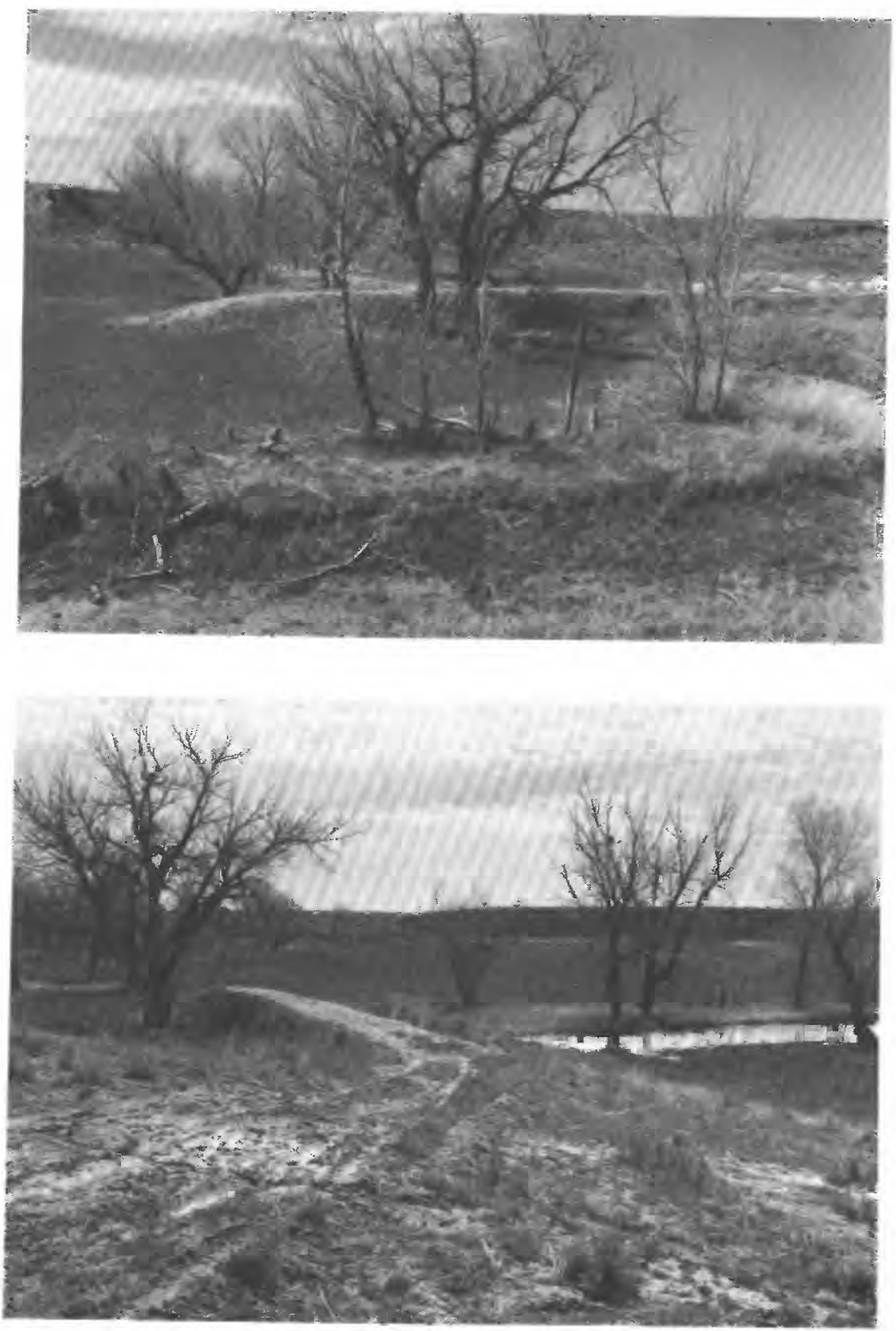

FIGURE 2.-Two views of the valley of Box Creek showing typical dikes used to divert flow from channel and irrigate the flood plain. 


\section{RUNOFF MEASUREMENTS}

To measure inflow from the upper part of the drainage basin, a gaging station equipped with a water-stage recorder was established in July 1956 on Box Creek at the bridge on State Route 59, and it is designated Box Creek near Bill, Wyo. In 1956 no measurable flow passed this gaging station; the 1957 record is discussed on page A-14. Another gaging station was established July 5, 1956, on Box Creek just above the confluence with Lightning Creek. It was equipped with a water-stage recorder in August 19,56. All surface outflow from Box Creek basin is measured at this site. This site was clearly not well suited for a gaging station because of the poorly defined channel and dense vegetation, but is was the only site possible for determining the outflow from the water-spreading area. Construction of a control to improve the record was too costly.

Both gaging stations were rated by current-meter measurements, and discharges were computed by use of the gage-height record and rating table.

For a more positive determination of disposition of water on the water spreader, it would have been desirable to have placed the upper gaging station at the head of the water spreader, rather than at State Route 59. This was precluded, however, by the lack of a suitable site and the relative inaccessibility of the upper part of the water spreader during storms.

Recognizing that significant quantities of runoff could enter the area from tributaries between the two gaging stations, estimates were made of these contributions by measuring runoff to stock reservoirs wherever available and by applying the unit runoff measured to the intervening tributary basins. The reservoirs were surveyed, a stagecapacity curve was constructed for each, and the runoff was computed volumetrically by noting the change in stage plus spill, which was computed by methods developed in making measurements at other reservoirs throughout the West (Kennon and Peterson, 1960, p. 87). In 1956, measurements were made on eight reservoirs; and in 1957, measurements were started on nine reservoirs. However, one dam (No. 9) was breached after the heavy storm of July 18, 1957, and the record for it, therefore, is not complete for the season. Observations of runoff at reservoir 1 were discontinued in 1957 because the spillway was badly eroded and storage reduced considerably. The station descriptions for each of these reservoirs and the record of runoff for individual runoff periods are given on pages $\mathrm{A}-39$ to $\mathrm{A}-44$.

\section{OBSERVATION WELIS}

After reviewing the data obtained in 1956, it was decided that several observation wells would be drilled on the valley floor in 1957 
in order to define the position of the ground-water level as a means of determining if inflow to the water spreader resulted in recharge to ground-water storage. Five shallow wells were drilled by the U.S. Geological Survey in July. (See fig. 1.) Although the water-level records cover only part of a season, some data on the depth to water level and fluctuations were obtained.

\section{SEDIMENTATION MEASUREMENTS}

In order to determine the quantity of sediment being deposited or trapped in the water-spreading area, two types of measurements were made. First, a system of six sedimentation ranges was established across the flood plain, virtually perpendicular to the line of flow. Recurrent surveys were made on these ranges to determine amounts of deposition or erosion. The original surveys were made in July 1956 and repeat surveys were made in Sepember 1956 and November 1957. Location of the ranges is shown in figure 3.

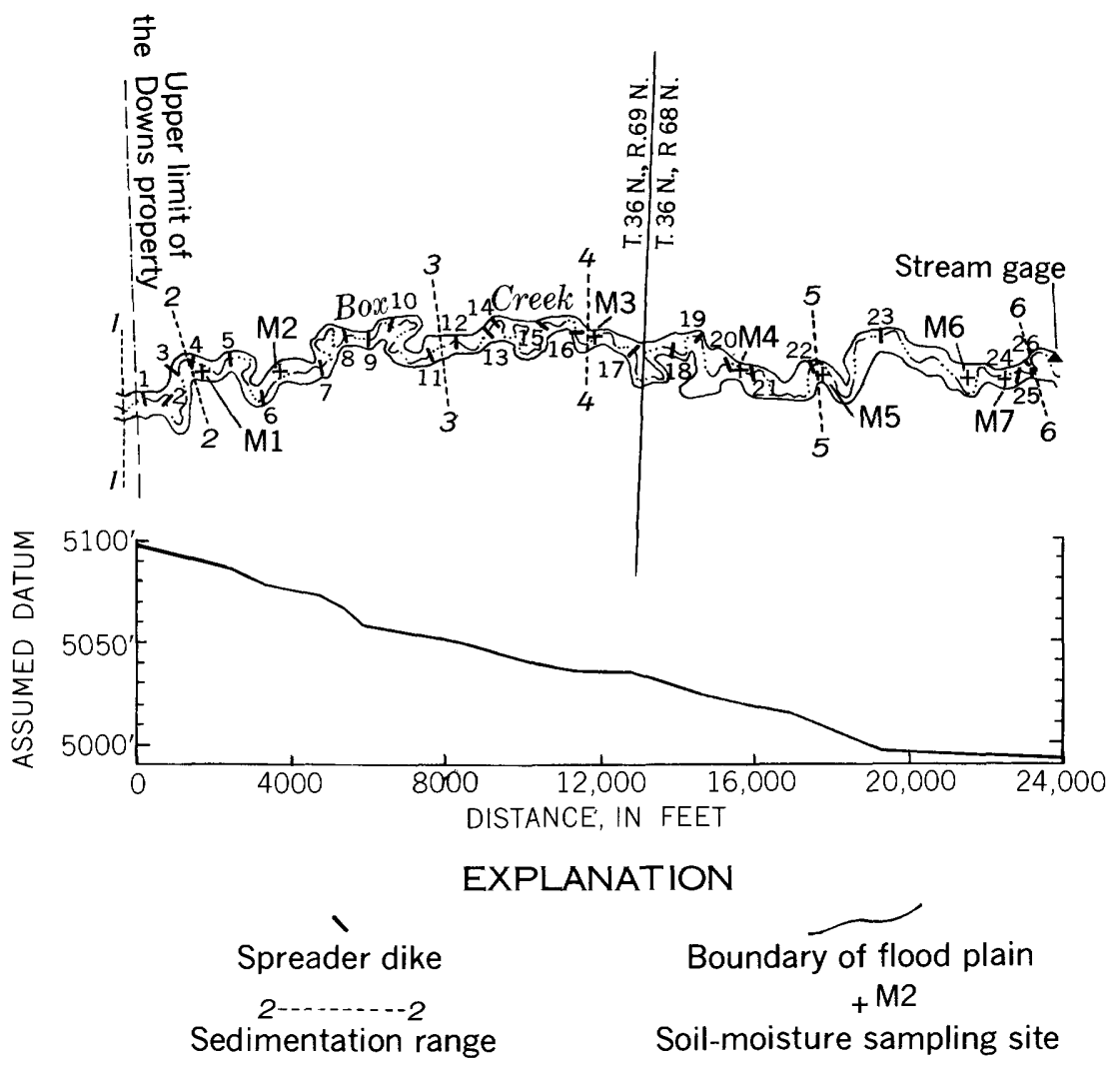

Figure 3.-Map and profile of Box Creek water spreader, showing location of dikes, sedimentation ranges, ' and sites for sampling soil moisture. 
In addition to the sedimentation ranges, the suspended-sediment load was measured during runoff periods at both the upper and lower stream-gaging stations. Inasmuch as the resident observer located at the Downs ranch could not make measurements at both stations during any single storm, a stationary sediment sampler, of the type recently developed by the Quality of Water Branch of the U.S. Geological Survey, was installed at the upper station on State Route 59. This sampler collected samples at intervals of 0.5 foot during each rise in stage. Samples also were collected manually when discharge measurements were made. At the lower station the sediment samples were obtained during each runoff period with a hand sampler in conjunction with discharge measurements. The suspended-sediment load for the 1957 season was computed from these samples and the runoff record.

\section{INFILTRATION TESTS}

To obtain preliminary information on the rate at which flood water might penetrate the valley floor, several infiltration tests were run with single- and double-ring infiltrometers. Data from these tests are presented in table 2 .

The single-ring infiltrometer is an open-ended cylinder forced into the ground. Water is poured into the cylinder and the rate at which it infiltrates in to the ground is measured. The double-ring infiltrometer consists of two concentric open-ended cylinders. Water is added to the same height in the smaller cylinder and in the annular space between cylinders. The moisture front moving downward below the annular space is supposed to restrain lateral spreading of the moisture front moving downward below the smaller cylinder where the infiltration rate is measured.

\section{SOIL-MOISTURE OBSERVATIONS}

To obtain information on the fluctuation of soil moisture in the spreading area, soil samples were taken at regular intervals in selected localities during the two seasons of observation. The soil-sampling points were distributed throughout the water-spreading area to provide a representation of the general conditions. (See fig. 3 for location.)

Samples were taken with a 2 -inch cylinder-type soil auger in 6-inch increments generally to a depth of 30 inches; but at some sites, where moisture conditions warranted it, sampling was continued to depths of as much as 42 inches. For most of the season each of the sites was sampled at intervals not exceeding 10 days, and as soon as possible after runoff occurred. Moisture-content determinations were made for the individual samples. Moisture-tension relationships also were determined for samples collected during 1957. 


\section{ANALYSIS OF PRECIPITATION DATA}

Daily precipitation records are presented in table 1 for the period of observation for all the gages operated in the study area during 1956 and 1957, including the record for the U.S. Weather Bureau gage Bill $14 \mathrm{SE}$. An inspection of this table shows the erratic distribution of rainfall in an area of only 15 square miles. Because of the limited record of both precipitation and runoff in the study area, the only means of appraising the data collected during the two seasons of this study, with respect to the probable long-term mean for the area, is by analyzing the longer records available for the U.S. Weather Bureau stations nearby. An examination of several records of precipitation and streamflow in eastern Wyoming shows that about 80 percent of the precipitation and about 85 percent of the runoff occur during the 6-month period, April through September. Experience in the Cheyenne River basin in recent years has substantiated this relationship. Therefore, in place of annual precipitation figures, seasonal precipitation figures for the stations at Dull Center and Douglas, Wyo., whose records are for more than 25 years, were used for this study. They were compared with the record for Bill $14 \mathrm{SE}$, which has been in operation for 9 years (1949-1957).

The first step in the analysis involved a comparison of the seasonal precipitation for Bill $14 \mathrm{SE}$, assumed to represent the Box Creek study area, with the seasonal precipitation covering the same period at Douglas and Dull Center to determine if the precipitation records were similar. The seasonal precipitation at Bill $14 \mathrm{SE}$ was plotted against the seasonal precipitation for Douglas and Dull Center in the double-mass diagram shown in figure 4. As shown, relationships for Bill $14 \mathrm{SE}$ and Douglas and Bill $14 \mathrm{SE}$ and Dull Center practically coincide. The line in figure 4 shows that the precipitation for Bill 14 $\mathrm{SE}$ is 1.10 of that for Douglas or Dull Center. Therefore, in the next step, which involved the use of the long-term records for Douglas and Dull Center, to determine the recurrence interval of the precipitation for the 1956 and 1957 seasons at Bill $14 \mathrm{SE}$, the amounts for Bill $14 \mathrm{SE}$ were divided by 1.10 .

The seasonal precipitation at Bill $14 \mathrm{SE}$ was markedly different during the 2 years of observation. In 1956 the total precipitation in the April-September period was 8.31 inches and in 1957 it was 12.22 inches, which when adjusted for the relationship in figure 4 become 7.55 and 11.10 inches, respectively. The recurrence interval of the 1956 seasonal precipitation, taken directly from the average of the Douglas and Dull Center frequency curves (fig. 5) is about 1.3 years. Therefore, although the precipitation in 1956 and resultant runoff, which is discussed on p. A-14, were sufficient to bring about only one complete wetting of the water spreader, the frequency analysis shows that the 
TABLE 1.-Precipitation in Box Creek area for periods July 11 to September 21, 1956, and May 16 to September 18, 1957

[No precipitation on days not listed. T, trace]

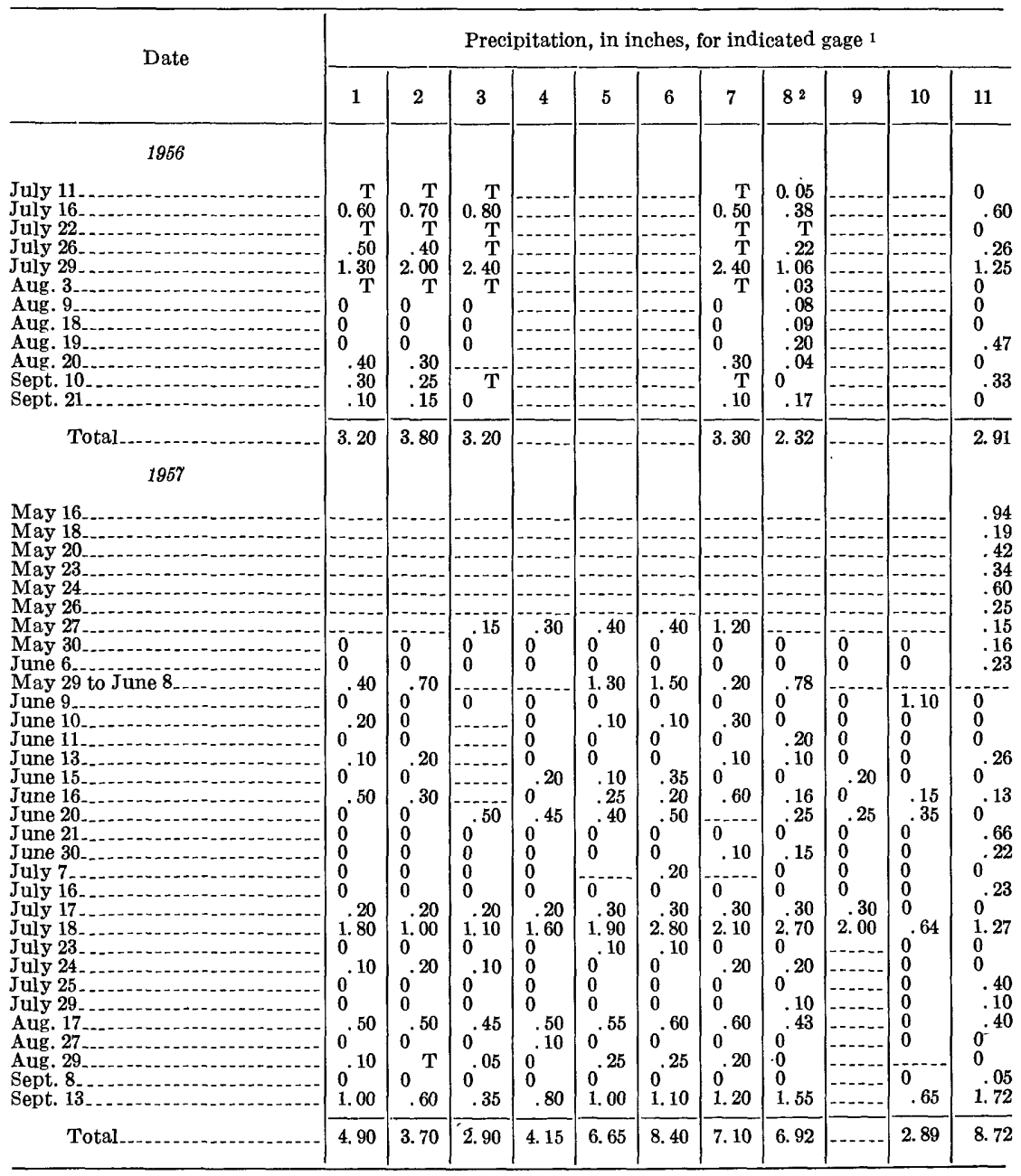

1 See figure 1 for gage location.

2 Standard nonrecording precipitation gage.

seasonal precipitation received in the 1956 season was not extremely low; on the average, the precipitation is lower for about 1 year out of 3 years. The 1957 seasonal precipitation has a recurrence interval of 2.8 years on the Dull Center curve and 4.0 years on the Douglas curve, or about 3.4 years for an average of the two curves.

During both seasons of observation there were some high rates of precipitation for periods of less than 24 hours. Because there were no recording gages operated in the area, storm intensities for shorter 


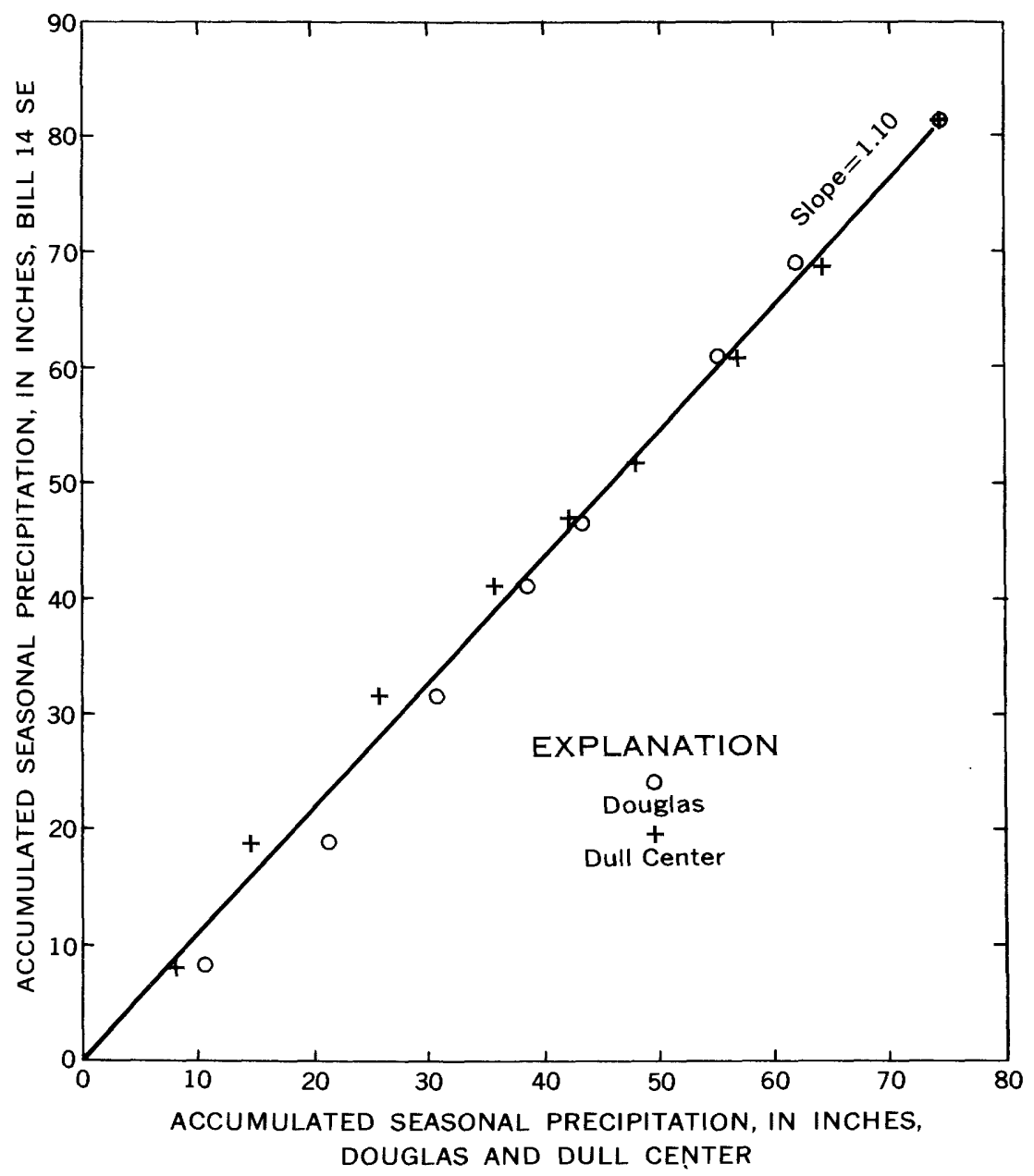

FigdRE 4.-Double-mass curve comparing seasonal precipitation at Bill 14 SE with that at Douglas and Dull Center, Wyo., for the period 1949 to 1957.

periods could not be determined. The largest daily precipitation amounts observed in the study area were 2.40 inches at gages 3 and 7 on July 29, 1956, and 2.80 inches and 2.70 inches at gages 6 and 8 respectively on July 18, 1957 . (See fig. 1 for location.) To obtain an indication of the frequency of such amounts in this area, frequency curves of annual maximum daily precipitation at Douglas and Dull Center were prepared and are shown in figure 6 . As indicated, the annual maximum daily precipitation amounts for Dull Center for all recurrence intervals are considerably higher during the period of record (1927-56) than those for Douglas (1924-56). Actually, the highest daily precipitation recorded for the State of Wyoming, 5.50 
WATER SPREADING IN BOX CREEK BASIN, WYOMING A-13

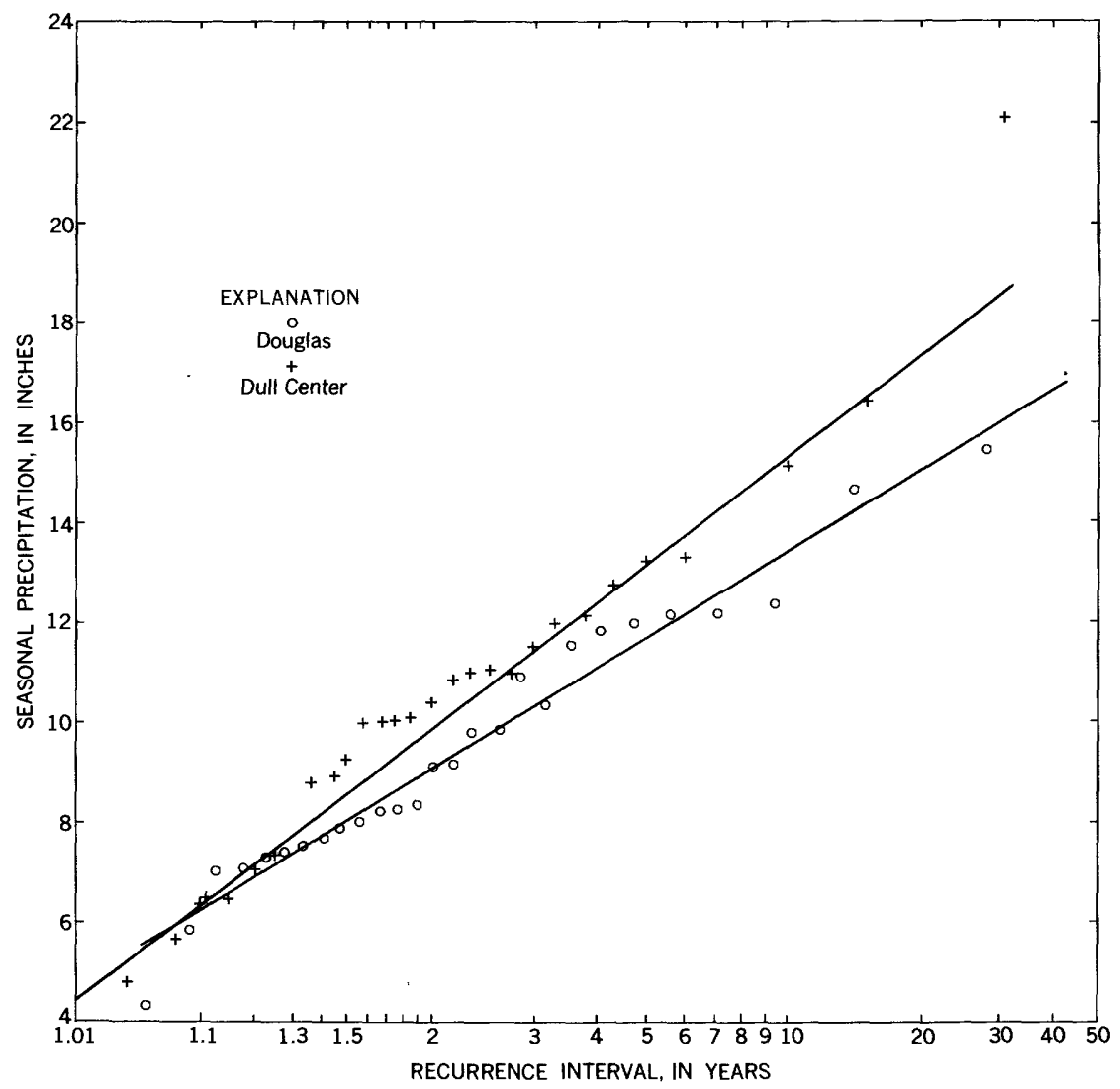

Figure 5.-Frequency curves of seasonal precipitation at Dull Center and Douglas, Wyo., for the period 1927-57, except for 1949 at Dull Center.

inches, occurred at Dull Center on May 31, 1927, whereas the maximum daily precipitation recorded for Douglas is 2.38 inches. On the basis of the curve for Dull Center (fig. 6), the amount of precipitation of 2.40 inches received in the study area on July 29,1956 , would have a recurrence interval of 6 years and the amount of 2.80 inches received July 18, 1957, would have a recurrence interval of 9 years. Comparison with the record for Douglas presents a somewhat different picture. On the basis of the record for Douglas, the maximum amount of precipitation (2.40 inches) received in 1956 in the study area would have a recurrence interval of 60 years and the maximum amount of precipitation (2.80 inches) received in 1957 would have an interval of approximately 100 years. A frequency curve of annual maximum daily precipitation at Bill $14 \mathrm{SE}$ is probably not meaningful for comparison with similar curves for Douglas and Dull Center because the record is only 9 years long. Also, an inspection of the precipitation data in table 1 shows that when the maximum amounts $6027150-61 \_3$ 


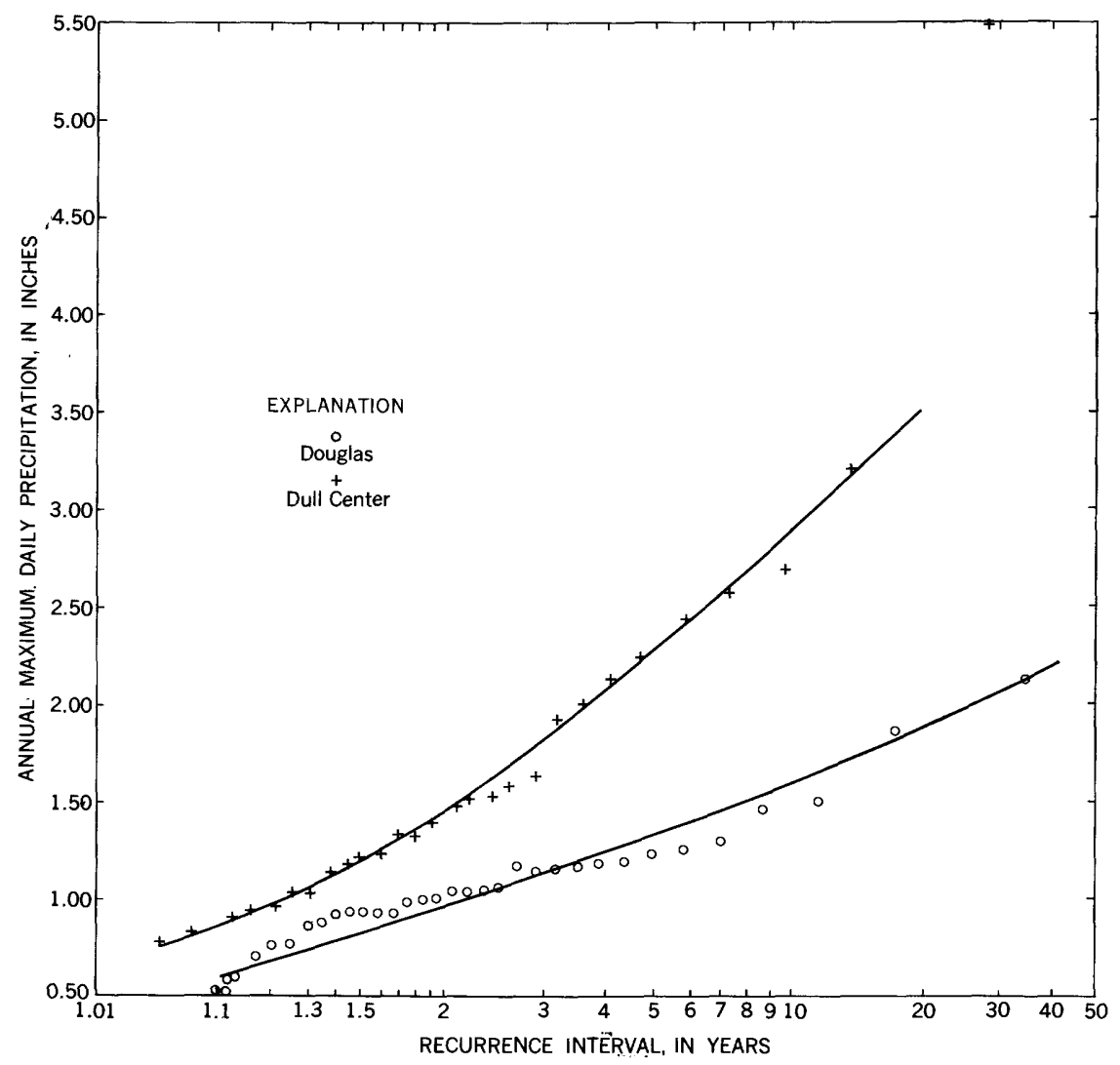

FiguRE 6.-Frequency curves of annual maximum daily precipitation at Douglas and Dull Center, Wyo., for the period $1924-57$.

of precipitation of 2.40 and 2.80 inches occurred in the Box Creek basin in 1956 and 1957, the recorded precipitation at Bill 14 SE was less than 1.50 inches both times. The large difference between these frequency curves for Dull Center and Douglas raise.considerable doubt as to the frequency of storms of the observed magnitude in the study area. It is believed, however, that owing to similarities in topography the storm conditions in the study area are more like those of Dull Center than those of Douglas and that the recurrence interval of the maximum storm in 1957 should be closer to 10 years than 100 years.

\section{RUNOFF DATA}

The streamflow records for the two gaging stations, Box Creek near Bill and Box Creek at mouth, are shown on pages A-15 and A-16. The upper gaging station, near Bill, is a conventional U.S. Geological Survey station and the complete record beginning with July 1956 was published by the Survey (1958) for water years 1956 and 1957 . The 
station at the mouth of Box Creek was operated only for the periods July 5 to September 25, 1956, and April 9 to October 31, 1957. Therefore, the records presented here are for the period when both stations were in operation.

The only flow passing either gaging station during the 1956 season resulted from a storm on July 29 , which was concentrated over the water spreader and downstream from the upper gage. The flow passing the lower station after this storm was computed as 98 acrefeet, based on indirect measurements.

\section{BOX CREEK NEAR BILL, WYO.}

Location.-Lat $43^{\circ} 06^{\prime}$, long $105^{\circ} 15^{\prime}$, in SE1/4 sec. 9, T. 36 N., R. 70 W., at bridge on State Route 59, and 9.7 miles south of Bill.

Drainage area.- $109 \mathrm{sq} \mathrm{mi}$.

Records available.-July 14, 1956 to Oct. 31, 1957 (see Water-Supply Paper 1509, p. 294, for conplete record).

Gage.-Water-stage recorder. Datum of gage is $4,694.12 \mathrm{ft}$ above mean sea level (State Highway bench mark).

Extremes.-Maximum discharge during record, 1,190 efs June 9 (gage height, $7.26 \mathrm{ft}$ ); no flow at times.

Remarks.- Records good, except that those showing discharge of more than $\mathbf{7 0}$ cfs are fair, and those for period of no gage-height record are poor. No flow July 14 to Dec. $7,1956$.

Discharge, in cubic feet per second, April 1 to October 31,1957

\begin{tabular}{|c|c|c|c|c|c|c|c|}
\hline Day & Apr. & May & June & July & Aug. & Sept. & Oct. \\
\hline${ }^{2}$ & $\begin{array}{l}0 \\
0 \\
0 \\
0 \\
0 \\
0 \\
0 \\
0 \\
0 \\
0 \\
0 \\
0 \\
0 \\
0 \\
0 \\
0 \\
0 \\
0 \\
0 \\
.4 \\
.3 \\
.1 \\
0 \\
.3 \\
.5 \\
.4 \\
.2 \\
.1 \\
0 \\
0 \\
0.0\end{array}$ & $\begin{array}{l}0 \\
.1 \\
.1 \\
.1 \\
.1 \\
.1 \\
.1 \\
.2 \\
.2 \\
.1 \\
.1 \\
.3 \\
.4 \\
1.1 \\
.9 \\
1.4 \\
* 7.7 \\
3.8 \\
2.9 \\
3.9 \\
28 \\
6.8 \\
3.9 \\
4.6 \\
* 67 \\
13 \\
* 8.9 \\
6.3 \\
* 3.4 \\
37 \\
35\end{array}$ & $\begin{array}{c}5.7 \\
3.1 \\
1.8 \\
1.4 \\
* 1.2 \\
1.0 \\
1.0 \\
1.2 \\
*_{51} \\
182 \\
11 \\
5.0 \\
* 3.4 \\
3.2 \\
2.3 \\
2.3 \\
2.6 \\
4.2 \\
2.6 \\
* 1.6 \\
* 29 \\
*^{*} 2 \\
9.2 \\
4.4 \\
2.7 \\
2.1 \\
2.1 \\
2.0 \\
1.4 \\
208\end{array}$ & $\begin{array}{r}22 \\
7.2 \\
3.8 \\
2.1 \\
1.4 \\
.9 \\
.5 \\
.4 \\
.3 \\
.2 \\
.1 \\
* .1 \\
1.3 \\
.6 \\
.2 \\
.1 \\
.1 \\
.1 \\
.1 \\
.1 \\
.2 \\
.1 \\
.1 \\
.1 \\
.1 \\
.1 \\
.1 \\
.1 \\
.1 \\
.1 \\
.1\end{array}$ & $\begin{array}{l}0 \\
0 \\
0 \\
0 \\
* 0 \\
0 \\
0 \\
.1 \\
.1 \\
0 \\
0 \\
0 \\
0 \\
0 \\
.1 \\
.1 \\
* .1 \\
.1 \\
.1 \\
.1 \\
.1 \\
1 \\
.1 \\
.1 \\
.1 \\
.1 \\
.1 \\
.1 \\
.2 \\
.2 \\
.1\end{array}$ & \begin{tabular}{c}
0.1 \\
.1 \\
.1 \\
.2 \\
.2 \\
.2 \\
.2 \\
.2 \\
.2 \\
.2 \\
.2 \\
.2 \\
. .6 \\
.2 \\
.2 \\
.2 \\
.2 \\
.2 \\
.2 \\
.2 \\
.2 \\
.2 \\
.2 \\
.2 \\
.2 \\
.1 \\
.1 \\
.1 \\
.1 \\
.1 \\
\hdashline.---
\end{tabular} & $\begin{array}{l}0.1 \\
.1 \\
.1 \\
.1 \\
.1 \\
.1 \\
.1 \\
.1 \\
.1 \\
.1 \\
.1 \\
.1 \\
.1 \\
.1 \\
.1 \\
.1 \\
.1 \\
.1 \\
.1 \\
.1 \\
.1 \\
.1 \\
.1 \\
.1 \\
.1 \\
.1 \\
.1 \\
.1 \\
.1 \\
.1 \\
.1\end{array}$ \\
\hline $\begin{array}{r}\text { Total } \\
\text { Mean } \\
\text { Acre-ft }\end{array}$ & $\begin{array}{l}2.3 \\
.08 \\
4.6\end{array}$ & $\begin{array}{l}237.5 \\
7.66 \\
471\end{array}$ & $\begin{array}{r}570.5 \\
19.0 \\
1130\end{array}$ & $\begin{array}{l}42.8 \\
1.38 \\
85\end{array}$ & $\begin{array}{l}2.2 \\
.07 \\
4.4\end{array}$ & $\begin{array}{c}5.6 \\
11\end{array}$ & $\begin{array}{l}3.1 \\
6.1\end{array}$ \\
\hline
\end{tabular}

*Discharge measurement or observation of no flow made on this day.

NoTE.-No gage-height record for Sept. 14-30; discharge estimated on basis of recorded range in stage . 


\section{BOX CREEK AT MOUTH, WYOMING}

Location.-Lat $43^{\circ} 07^{\prime} 10^{\prime \prime}$, long $105^{\circ} 02^{\prime} 30^{\prime \prime}$, in $\mathrm{NW} 1 / 4 \mathrm{SW} 1 / 4$ sec. $4, \mathrm{~T}$. $36 \mathrm{~N}$, R. $68 \mathrm{~W}$., on left bank half a mile downstream from the Downs Ranch.

Drainage area. $-158 \mathrm{sq} \mathrm{mi}$, approximately.

Records available.-July 5 to Oct. 31, 1956, and Apr. 9 to Oct. 31, 1957.

Gage.-Water-stage recorder. Altitude of gage, 4,996.67 ft, assumed datum.

Extremes.-Maximum discharge during record, 813 cfs July 18, 1957 (gage height, $11.29 \mathrm{ft}$ ); no flow at times.

Remarks.-Records fair for periods of low to medium flow; poor for periods of high flow.

Water year 1956.-No flow July 5 to Oct. 31, 1956, except for July 29 (98 acre-feet).

Discharge, in cubic feet per second, April 9 to October 31, 1957

\begin{tabular}{|c|c|c|c|c|c|c|c|}
\hline Day & Apr. & May & June & July & Aug. & Sept. & Oet. \\
\hline & & $\begin{array}{l}0 \\
0\end{array}$ & $\begin{array}{ll}34 \\
3.8\end{array}$ & $\begin{array}{r}* 136 \\
36\end{array}$ & & $\begin{array}{l}\mathbf{0} \\
\mathbf{0}\end{array}$ & \\
\hline$\cdots$ & & 0 & .5 & 6.7 & & 0 & - \\
\hline & $\cdots$ & 0 & 0 & $0^{.6}$ & & 0 & - \\
\hline & . & 0 & 0 & 0 & & 0 & - \\
\hline 8.-- & ........... & $\begin{array}{l}0 \\
0\end{array}$ & $\begin{array}{l}0 \\
0\end{array}$ & ${ }_{0}^{0}$ & & $\begin{array}{l}0 \\
0\end{array}$ & $-1, \ldots$ \\
\hline & & 0 & 0 & 0 & & 0 & \\
\hline & 0 & 0 & $* 75$ & 0 & $\mathrm{~L}$ & 0 & - \\
\hline $11-$ & $\begin{array}{l}0 \\
0\end{array}$ & 0 & ${ }^{* 84}$ & 0 & & 0 & -... \\
\hline & 0 & 0 & $\begin{array}{c}10 \\
2.8\end{array}$ & 0 & & $*_{63}$ & - \\
\hline 14 & $\begin{array}{l}0 \\
0\end{array}$ & $0^{.4}$ & $0^{.5}$ & $\begin{array}{l}0 \\
0\end{array}$ & & ${ }_{1}^{17}$ & $-\ldots+n$ \\
\hline 16 & 0 & 6.2 & 0 & 0 & ...- & 0 & (n) \\
\hline 18 & 0 & $\begin{array}{c}57 \\
7.1\end{array}$ & $0^{.8}$ & $\begin{array}{r}0 \\
127\end{array}$ & 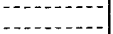 & 0 & - \\
\hline $19 \ldots \ldots \ldots$ & 0 & 5.9 & 0 & *57 & $\ldots \ldots$ & 0 & - \\
\hline & $\begin{array}{l}0 \\
0\end{array}$ & 1.0 & *33 & $0^{3}$ & $\cdots$ & $\begin{array}{l}0 \\
0\end{array}$ & - \\
\hline . & 0 & $*_{30}^{41}$ & 8.8 & 0 & - & 0 & - \\
\hline . & 0 & $* 26$ & 33 & 0 & $\mid$ & 0 & - \\
\hline $\begin{array}{c}-1 \\
-12-1\end{array}$ & $\begin{array}{l}0 \\
0\end{array}$ & $\begin{array}{l}*_{138}^{*} 58 \\
*_{138}\end{array}$ & $\begin{array}{l}6.8 \\
1.0\end{array}$ & $\begin{array}{l}0 \\
0\end{array}$ & $\mid$ & $\begin{array}{l}0 \\
0\end{array}$ & - \\
\hline 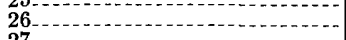 & 0 & 60 & 0 & 0 & - & 0 & - \\
\hline & 0 & ${ }_{* 20}^{* 20}$ & 0 & $\begin{array}{l}0 \\
0\end{array}$ & - & $0_{0}^{0}$ & -no \\
\hline$\cdots$ & 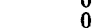 & 33 & 0 & 0 & $\cdots$ & 要 & \\
\hline F & 0 & 1.8 & & 0 & $\ldots$ & & \\
\hline at $>>$ & & & & & & & \\
\hline & & & & & 0 & & $\begin{array}{l}0 \\
0\end{array}$ \\
\hline Acre-ft.-. & & 1155 & $593^{3.90}$ & & 0 & & 0 \\
\hline
\end{tabular}

*Discharge measurement made on this day.

NотE.-No gage-height record for July 5 to Aug. 5, 1956, and Sept. 26 to Oct. 31, 1956; discharge estimated on basis of field observations, weather records, and records for nearby stations.

The record for the upper station, which was in operation for the entire month of April 1957, shows a small base flow for 8 days and no storm runoff. There was no flow at the lower station from the time observations were begun on April 9 to the end of the month. The first storm runoff of the season at both stations occurred on May 14. The observed flow during May at the upper station was 471 acre-feet, and the outflow past the station at the mouth of Box Creek was 1,155 acre-feet, which indicates a contribution of 684 acre-feet from the intervening area. The runoff records for the 
observation reservoirs are not complete for the period May 14-31, because high runoff made roads impassable and regular measurements were impossible. Therefore, the distribution of runoff contributions from tributaries between the gaging stations cannot be defined reliably for this period.

During June, flow occurred on all days at the upper station and on 14 days at the lower station. There were two storms in June 1957, which were centered in the headwaters of Box Creek basin with no inflow to the channel below the upper gaging station. The records for both of these runoff periods show a high loss in runoff and suspended-sediment load in the reach between the gaging stations, reflecting the effect of the water-spreading system on streamflow and sediment discharge when the record is not complicated by tributary runoff. The data for these two storms and their significance are discussed on pages A-22 to A-23.

After July 5, 1957, flow past the upper gaging station was negligible for the remainder of the season, or until the study was concluded on October 31. However, two storms occurred on July 18-19 and September 14-15 that were limited virtually to the part of the drainage basin directly tributary to the water-spreading area. Both resulted in high streamflow at the mouth of Box Creek.

In comparing total flow past the two gaging stations for the 1957 season, the outflow at the mouth of Box Creek exceeded the inflow at the upper station by 922 acre-feet. This is due to contributions from the drainage area between the gaging stations. In determining the contributions from tributary basins, observations of runoff to stock reservoirs were used to construct runoff maps for selected storm periods. Data collected at these reservoirs during the 1956 and 1957 seasons are given on pages $\mathrm{A}-39$ to $\mathrm{A}-45$.

\section{DISPOSITION OF STREAMFLOW ON THE WATER SPREADER}

\section{COMPUTATIONS BASED ON STREAMFLOW RECORDS}

The disposition of streamflow on the water spreader for six selected periods during the two seasons of observation was computed from the gaging-station records, mapped runoff based on reservoir observations, and fluctuations of soil moisture during storm periods. A summary of the computations for the disposition of runoff during the six selected periods is shown in table 3.

Only two storms produced runoff during the summer of 1956 . The first, on July 16, was small in areal extent and produced no flow at the mouth of Box Creek. The second storm which occurred on July 29 produced high outflow from the water spreader. The disposition of water in both of these storms was computed by mapping the runoff 
based on reservoir observations and comparing this with outflow past the lower gaging station. The distribution of reservoirs was not uniform and, therefore, the isograms of equal runoff shown on figure 7 were started from areas of known runoff intensity and extended on the basis of precipitation, topography, vegetation, and inspection of high-water marks in tributaries where quantitative data were not available. Runoff maps were prepared for both the 1956 storms, but only the map of the July 29 storm is included here as an example of the method used.

The storm of July 16, 1956, produced a net runoff of 16 acre-feet from the uncontrolled drainage area tributary to the water spreader. In addition, there was a direct contribution of precipitation to the spreader of 11 acre-feet, based on the average rainfall measured in the gages. Since no outflow occurred at the mouth of Box Creek, a total of 27 acre-feet was lost through infiltration and evaporation in shallow tributaries and the main stream channel and flood plain. Runoff from this storm was spread over an area of less than 10 acres and no precise measurements of soil-moisture changes were made.

The storm of July 29, 1956, was intense but of small areal extent, producing a net runoff of 243 acre-feet as computed from the runoff map (fig. 7). The storm appeared to center near the Downs ranch, where the precipitation was 2.4 inches, and extended upstream about 8 miles. In addition to the runoff entering the water-spreading area, precipitation records show that rainfall directly contributed 55 acrefeet of water to the water spreader. Therefore, the total amount of water entering the water spreader was 298 acre-feet. The outflow was estimated to be 98 acre-feet, which makes an estimated retention by the spreader of 200 acre-feet.

Estimates from soil-moisture data (p. A-30) indicate a net increase of 200 acre-feet of water in the soil moisture on the water spreader. This amount coincides with the estimates from inflow-outflow records.

The infiltration rate as indicated by eight ring-infiltrometer tests was 2.26 inches per hour for the interval of 40 to 60 minutes. The flow for this storm persisted for 3 to 4 hours. This would indicate a possible infiltration on the water spreader of 230 acre-feet, based on the above rate. However, the average infiltration rate for 3 or 4 hours may be less than that of the 40- to 60-minute interval (table 2).

Two intense storms on July 18 and September 13, 1957, were centered over the water-spreading area and adjacent slopes, but they did not produce runoff at the upper gaging station. The disposition of water is shown in table 3 .

Owing to the large amount of spill at the observation reservoirs, the failure of the dam at reservoir 9 after catching 125 acre-feet of runoff, and the general erratic distribution of the runoff, a runoff map for the 
WATER SPREAdiNG IN BOX CREeK basin, WYOMING A-19

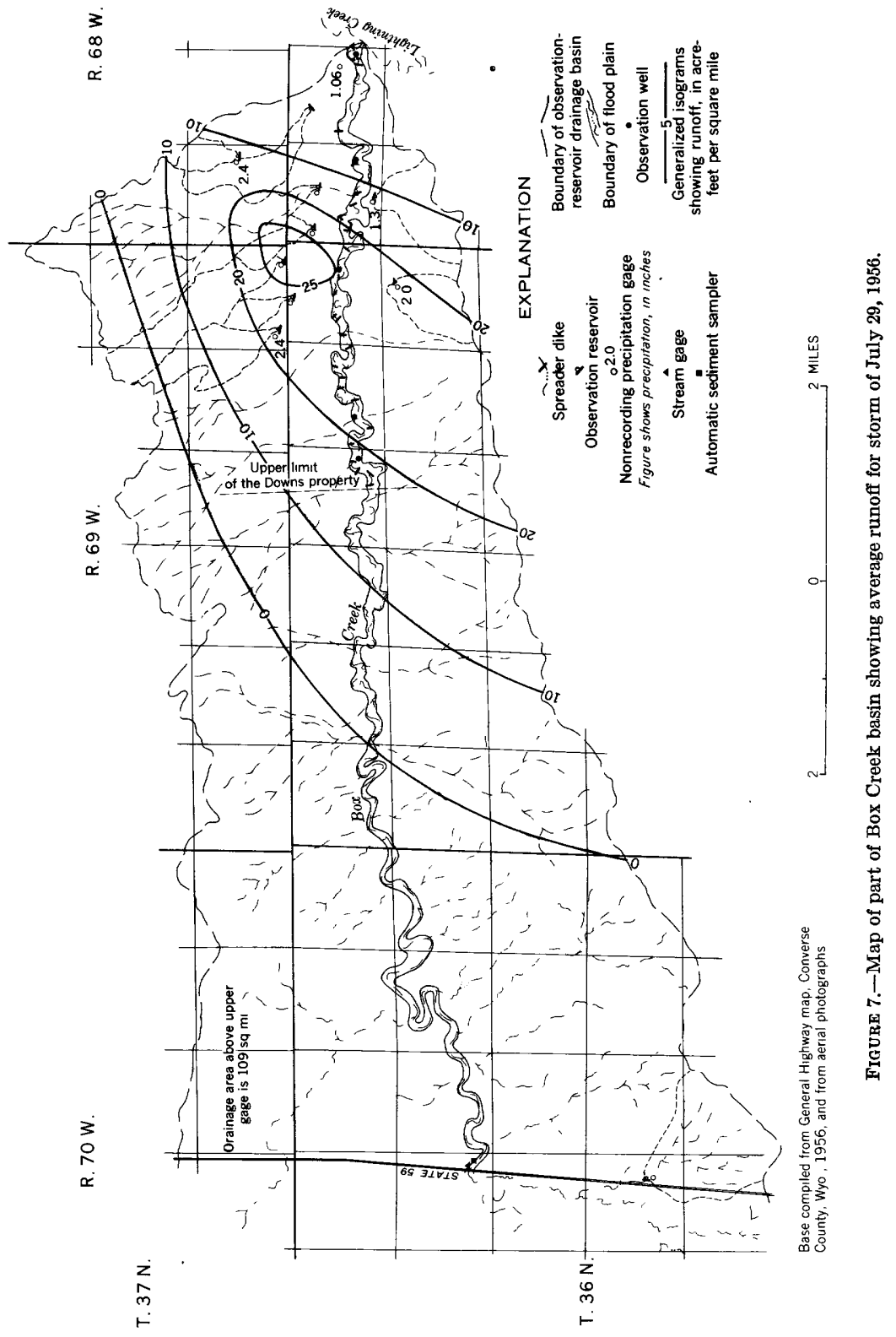


TABLE 2.-Infiltration rates from ring infiltrometer tests

\begin{tabular}{|c|c|c|c|c|c|c|c|c|c|c|c|}
\hline \multirow{2}{*}{ Location and date of test } & \multicolumn{10}{|c|}{$\begin{array}{c}\text { Infiltration rates, in inches per hour, for indicated } \\
\text { elapsed time (minutes) }\end{array}$} & \multirow{2}{*}{$\begin{array}{l}\text { Average } \\
\text { rate per } \\
\text { hour } \\
\text { during } \\
\text { last } \\
\mathbf{2 0} \text { min. }\end{array}$} \\
\hline & 2 & 4 & 10 & 15 & 20 & 25 & 30 & 40 & 50 & 60 & \\
\hline $\begin{array}{l}75 \mathrm{ft} \text {. below dike } 4 \text {, July } 5,1956 \\
150 \mathrm{ft} \text {. below dike } 4 \text {, July } 5,1956 \\
100 \mathrm{ft} \text {. below dike } 16 \text {, July } 5,1956 \\
200 \mathrm{ft} \text {. below dike } 16 \text {, July } 5,1956 \\
75 \mathrm{ft} \text {. below dike } 22, \text { July } 6,1956 \\
\text { Below dike } 22 \text {, Aug. } 16,1956 \\
\text { Below dike 23, Aug. } 16,1956\end{array}$ & $\begin{array}{r}6 \\
30 \\
6 \\
6 \\
12 \\
36 \\
66\end{array}$ & $\begin{array}{r}6 \\
6 \\
6 \\
6 \\
6 \\
18 \\
24\end{array}$ & $\begin{array}{r}1.5 \\
2.5 \\
3.5 \\
3.8 \\
3.7 \\
10.8 \\
16.8\end{array}$ & $\begin{array}{l}1.8 \\
3.5 \\
3.5 \\
4.5 \\
2.4 \\
4.8 \\
9.6\end{array}$ & $\begin{array}{l}0.5 \\
2.5 \\
2.5 \\
4.5 \\
1.8 \\
3.6 \\
8.4\end{array}$ & $\begin{array}{l}1.3 \\
1.3 \\
2.5 \\
2.5 \\
1.8 \\
3.6 \\
7.2\end{array}$ & $\begin{array}{l}1.3 \\
1.3 \\
2.5 \\
3.6 \\
2.5 \\
3.0 \\
4.8\end{array}$ & $\begin{array}{l}1.3 \\
1.2 \\
2.4 \\
3.6 \\
1.8 \\
3.0 \\
6.6\end{array}$ & $\begin{array}{l}0.9 \\
1.2 \\
2.4 \\
2.4 \\
1.2 \\
2.4 \\
3.6\end{array}$ & $\begin{array}{l}0.9 \\
1.2 \\
1.5 \\
2.4 \\
1.8 \\
2.4 \\
2.4\end{array}$ & $\begin{array}{l}1.0 \\
1.2 \\
2.1 \\
2.8 \\
1.6 \\
2.6 \\
4.2\end{array}$ \\
\hline $\begin{array}{l}\text { Near month of Box Creek, } \\
\text { Aug. 10, 1956 }\end{array}$ & 36 & 18 & 10.8 & 4.8 & 3.6 & 3. 6 & 3. 6 & 3.0 & 3.0 & 2.4 & 2.8 \\
\hline
\end{tabular}

storm of July 18 was not prepared. Therefore, the disposition of runoff had to be obtained in another way.

The outflow at the lower gaging station was 366 acre-feet. The soil-moisture records indicate that 66 acre-feet was retained by infiltration in the water spreader. This would make a total of at least 432 acre-feet available. The precipitation on the water spreader was estimated as 57 acre-feet, which leaves 375 acre-feet as the runoff from drainage areas tributary to the water spreader.

The storm of September 13, 1957, was centered over the waterspreading area, and because water levels in the observation reservoirs were low after a dry period in August, only slight spill occurred and, therefore, the records were adequate for the preparation of a runoff map (fig. 8). The net inflow into the water-spreading area, as computed from the runoff map, was 250 acre-feet and direct precipitation on the water spreader was 29 acre-feet, making a total of 279 acre-feet of water available.

The outflow past the lower gaging station was 158 acre-feet; therefore, 121 acre-feet was retained by the water spreader.

TABLE 3.-Disposition of streamflow, in acre-feet, in Box Creek during selected periods, 1956-57

\begin{tabular}{|c|c|c|c|c|c|c|}
\hline Runoff period & $\begin{array}{c}\text { Observed } \\
\text { flow at } \\
\text { Box Creek } \\
\text { near Bill }\end{array}$ & $\begin{array}{l}\text { Net runoff } \\
\text { between } \\
\text { gaging } \\
\text { stations }\end{array}$ & $\begin{array}{l}\text { Precipita- } \\
\text { tion on } \\
\text { spreading } \\
\text { area }\end{array}$ & Sum & $\begin{array}{l}\text { Outflow } \\
\text { past Box } \\
\text { Creek at } \\
\text { mouth }\end{array}$ & $\begin{array}{l}\text { Retention } \\
\text { in water } \\
\text { spreader }{ }^{1}\end{array}$ \\
\hline 1956 & \multirow{3}{*}{$\begin{array}{l}0 \\
0\end{array}$} & \multirow{3}{*}{$\begin{array}{r}16 \\
243\end{array}$} & \multirow{3}{*}{$\begin{array}{l}11 \\
55\end{array}$} & \multirow{3}{*}{$\begin{array}{r}27 \\
298\end{array}$} & \multirow{3}{*}{$\begin{array}{r}0 \\
298\end{array}$} & \multirow{3}{*}{$\begin{aligned} 27 \\
200\end{aligned}$} \\
\hline July 16- & & & & & & \\
\hline 1957 & & & & & & \\
\hline $\begin{array}{l}\text { June } 9-14 \\
\text { June } 30 \text { to July } 4 \\
\text { July } 18-20\end{array}$ & $\begin{array}{r}508 \\
482 \\
0\end{array}$ & $\begin{array}{r}0 \\
0 \\
375\end{array}$ & $\begin{array}{l}0 \\
0\end{array}$ & $\begin{array}{r}508 \\
482\end{array}$ & $\begin{array}{l}352 \\
356 \\
366\end{array}$ & $\begin{array}{l}156 \\
126 \\
866\end{array}$ \\
\hline Sept. 13-15. & 0 & 250 & 29 & 279 & 158 & 121 \\
\hline
\end{tabular}

1 For estimates of inflitration based on soil-moisture observations, see p. A-30.

2 Discharge estimated from indirect measurements.

3 Estimated from soil-moisture changes. 


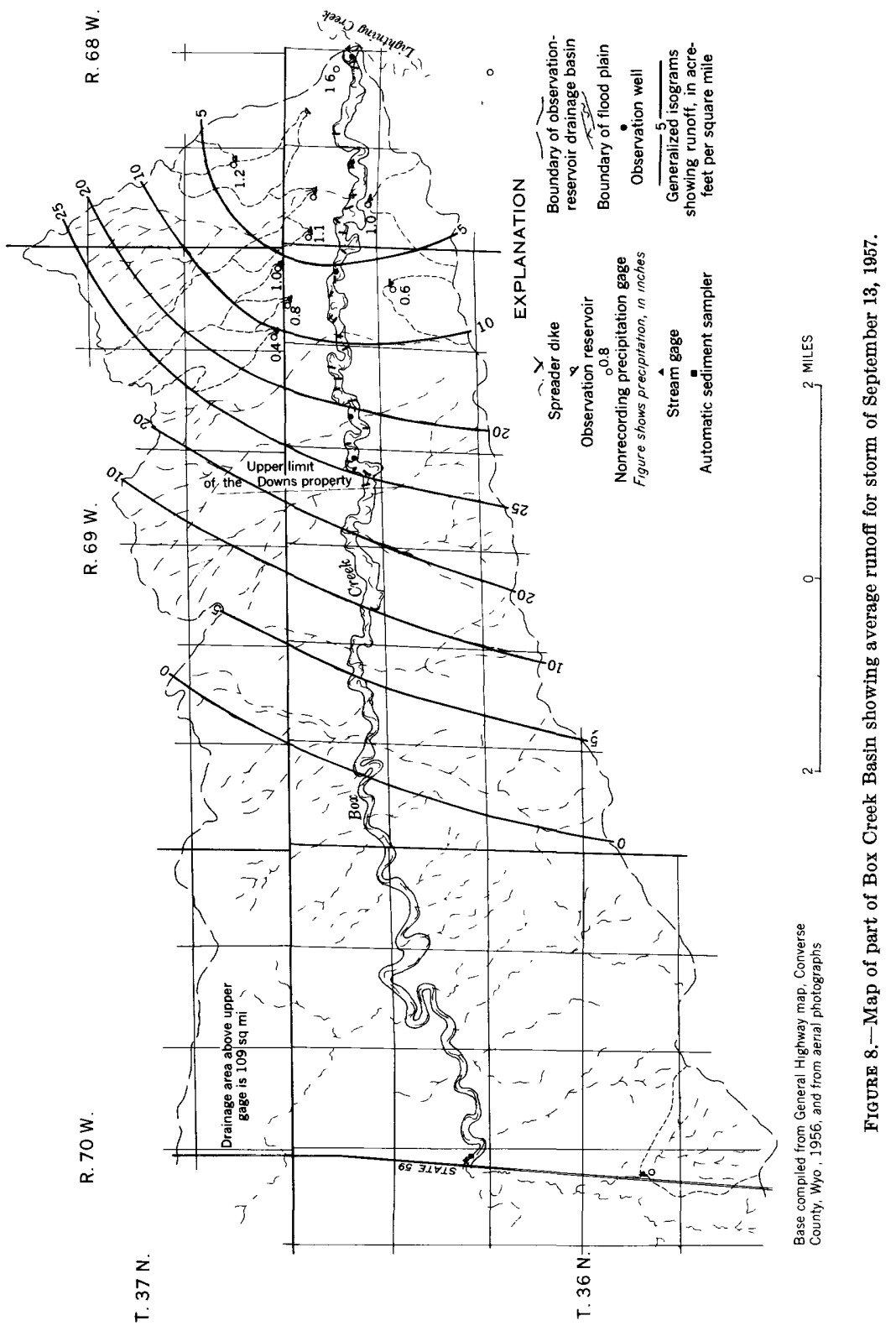


As previously mentioned, there were two storms during the 1957 season that centered in the headwaters of Box Creek, and all runoff produced by these storms originated above the upper gaging station. These runoff periods were June 9-14 and June 30 to July 4. During these two periods there was no runoff from tributaries below the upper gage.

Before the storm of June 9, the water spreader was flooded several times in May by runoff originating from upstream sources and tributaries adjacent to the water spreader. Therefore, soil moisture was high and conditions were not ideal for absorption of flood water on the valley floor. Data from other runoff periods show that antecedent moisture conditions are important in determining how much peak discharge and flood volume are reduced in passing through the water spreader.

The flood hydrographs at both gaging stations for the period June 9-14 are shown in figure 9. Runoff from this storm reached the upper gage at 11:00 p.m. on June 9, and by 11:30 p.m. the discharge had reached an instantaneous peak of $1,190 \mathrm{cfs}$ (cubic feet per second). The outflow at the lower gaging station did not begin until 3:30 p.m. on June 10, and the instantaneous peak discharge was $276 \mathrm{cfs}$ at 5:30 p.m. Much of the lag between inflow and outflow may be attributable to the impeding action of the diversion dams. The outstanding feature of the two hydrographs is the large reduction in peak discharge between the gaging stations. The peak discharge at the lower station was only 23 percent of that measured at the upper station.

The volume of runoff at the upper gage, as determined from the hydrograph, was 508 acre-feet and the outflow at the mouth of Box Creek was 352 acre-feet. Since no measurements are available for the volume of water absorbed in the reach of channel between the upper gage and head of the water spreader, the loss of 156 acre-feet represents

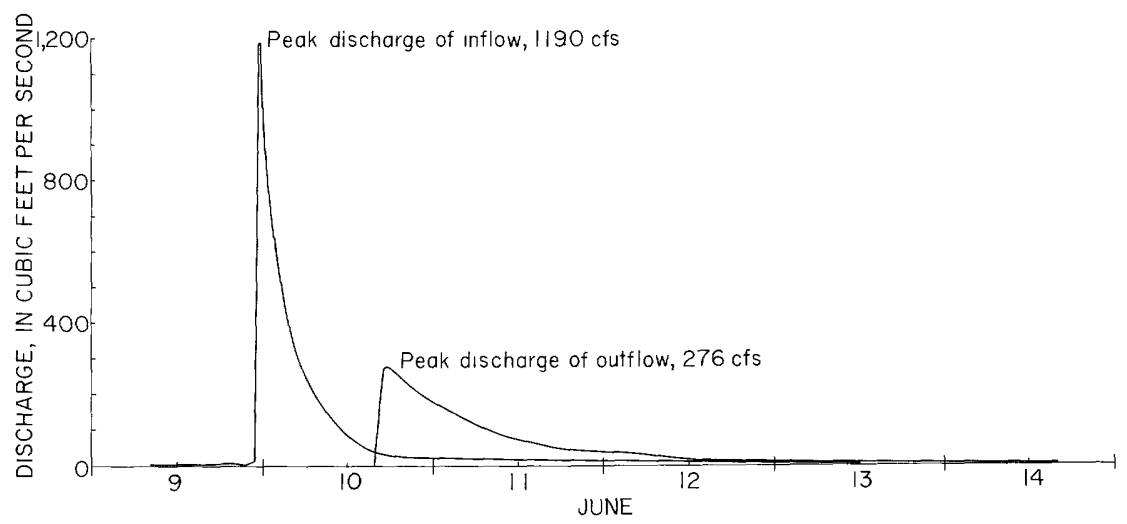

FIGURE 9.-Flood hydrographs for gaging stations at Box Creek for the period June 9-14, 1957. 
the retention in the entire reach between the two gages. However, it is believed that only a small part of the loss is attributable to the channel and flood plain above the water spreader. Also, it is assumed that evaporation and transpiration losses are negligible during any single runoff period.

The flood hydrographs at both gaging stations for the period June 30 to July 4, 1957, are shown in figure 10. The instantaneous peak discharge at the upper gaging station was $840 \mathrm{cfs}$ and the outflow peak discharge was only $247 \mathrm{cfs}$ at the mouth of Box Creek. This represents a reduction in peak discharge of 71 percent after passing through the water-spreading area.

The volume of observed flow at the upper gage was 482 acre-feet during the period June 30-July 4. Outflow at the lower gaging station began on July 1 and lasted until July 4, and the volume was only 356 acre-feet. Again, the loss of 126 acre-feet represents retention in the entire reach between gaging stations, but most of this is probably attributable to the water spreader.

The infiltration differences in the six runoff periods shown in table 2 are attributable in some degree to variations in soil moisture and ground-water levels. When soil moisture is high, the opportunity for storage of water in the spreading area is less than when there is a long period between runoff events and the soil is dry.

In summary, the total inflow for the six runoff periods was 2,026 acre-feet and the outflow was 1,330 acre-feet, which represents a loss of 34 percent of surface flow entering the water spreader.

\section{FLUCTUATION OF GROUND-WATER LEVELS}

The five observation wells that were drilled in July 1957 reached a perched water table within the alluvial fill of Box Creek valley at depths ranging from 4 to 13 feet. (See fig. 11.) The thickness and lateral extent of the perched water body was not determined, but it is assumed that saturation does not extend through bedrock to any

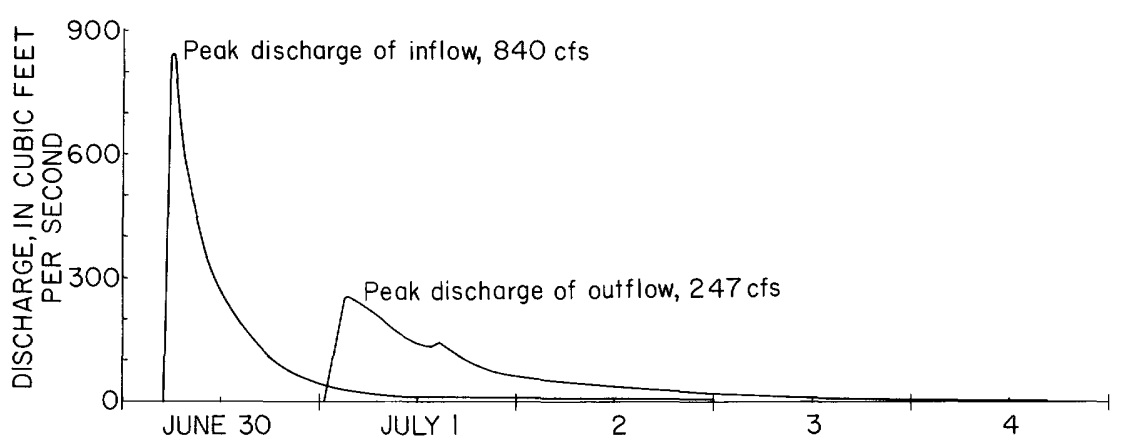

FIGURE 10.-Flood hydrographs for gaging stations at Box Creek for the period June 30 to July 4, 1957. 


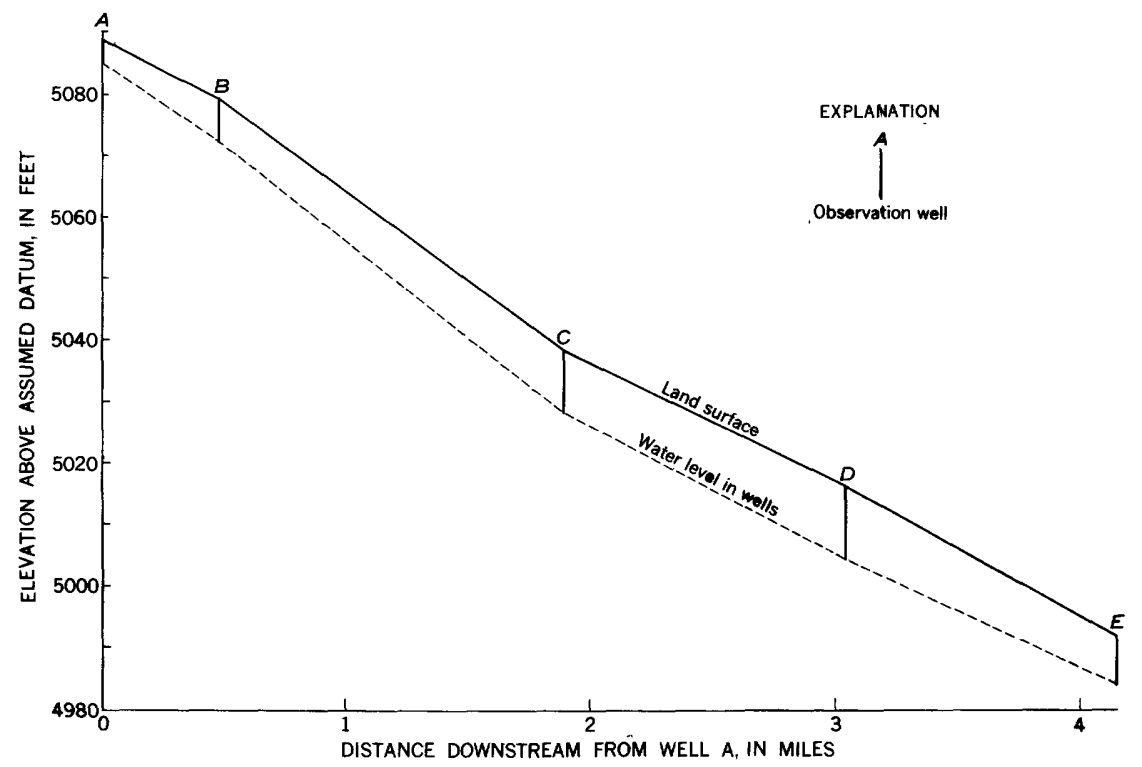

FIGURE 11.-Graph showing land surface and water level in Box Creek water-spreading area, July 10, 1957.

considerable depth. The depth of Mr. Downs' cased well at the ranch headquarters indicates a regional water table at depths of more than 300 feet, which is probably not connected with the perched water within the water-spreading area.

Figure 12 shows hydrographs of five observation wells in the Box Creek water-spreading area for a 10-week period. Two floods occurred during the period, but there were no observations made at well $D$ from July 18 to August 9 and at well E from July 18 to August 14 (fig. 12). Therefore, it is not known how the water level in these two wells responded to the flood of July 18. Measurable fluctuations in water levels were recorded at wells A and B after the flood of July 18. Well A showed significant response to the flood of September 13, and well E showed a minor response. During the period August 16-20, a small rise in water level was noted in well $A$. This probably was the result of infiltration following a small ponding of flow behind dike 4, located 30 feet upstream from well $\mathrm{A}$.

It may be inferred from the observational data that some water entering the water spreader penetrates to the perched water table at the upper end of the dike system. However, this effect is less noticeable downstream.

\section{FLUCTUATIONS IN SOIL-IMOISTURE CONTENT AND THEIR INTERPRETATION}

The purpose of the program of soil-moisture sampling in this study was to show the consumptive use of water by the water spreader and 
WATER SPREADING IN BOX CREEK BASIN, WYOMING A-25
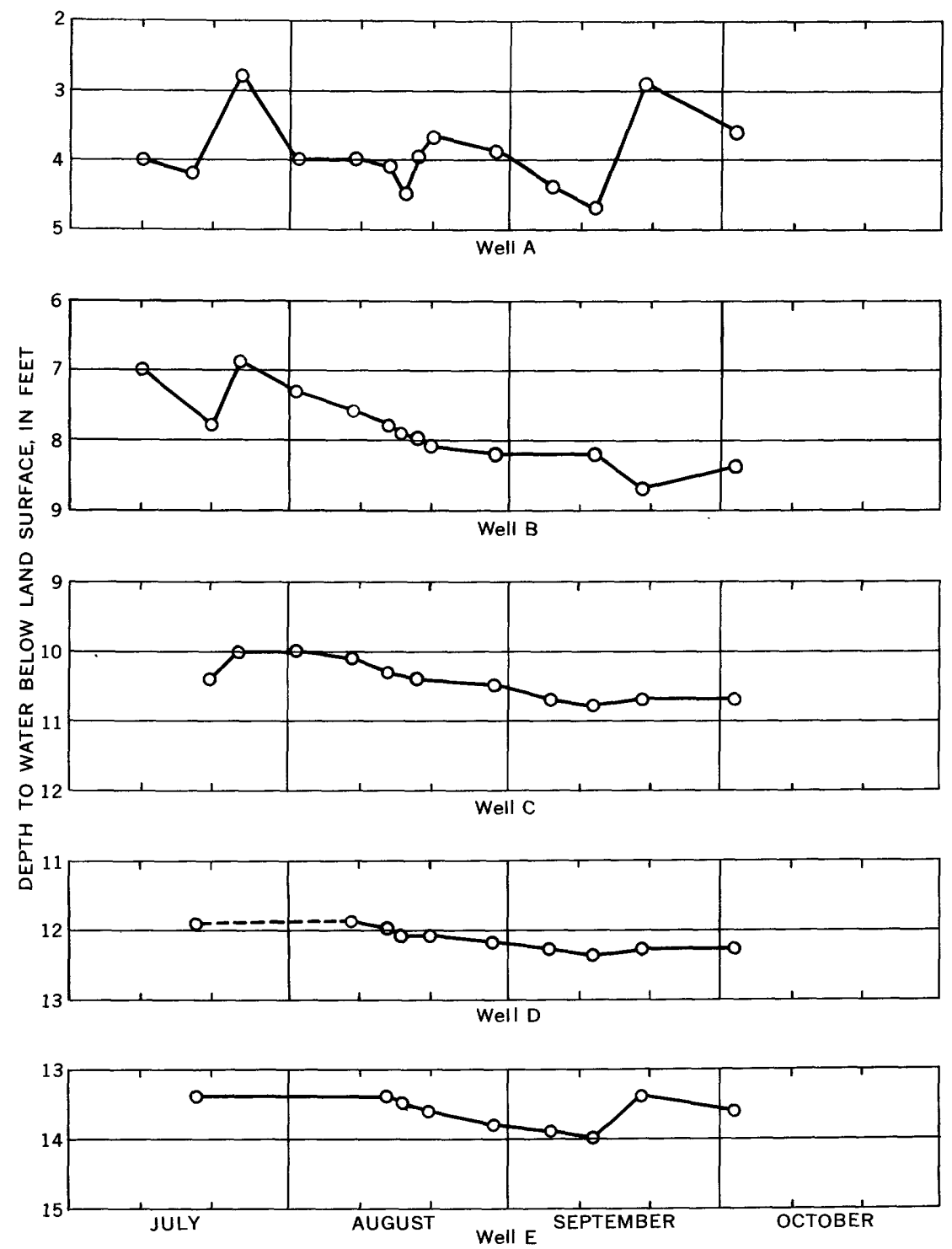

FIGURE 12.-Hydrographs of five observation wells in the Box Creek water-spreading area, 1957.

to check the absorption of water on the water spreader during storms as computed from inflow, from precipitation, and from outflow records.

Complete records of soil-moisture content are given on pages A-44 to A-46. Because the zone of usable moisture storage for rangeland grasses is concentrated mainly within 12 inches of the surface, records for samples taken at the 12-inch depth were plotted in figure 13 for all sampling sites for the years 1956 and 1957. 


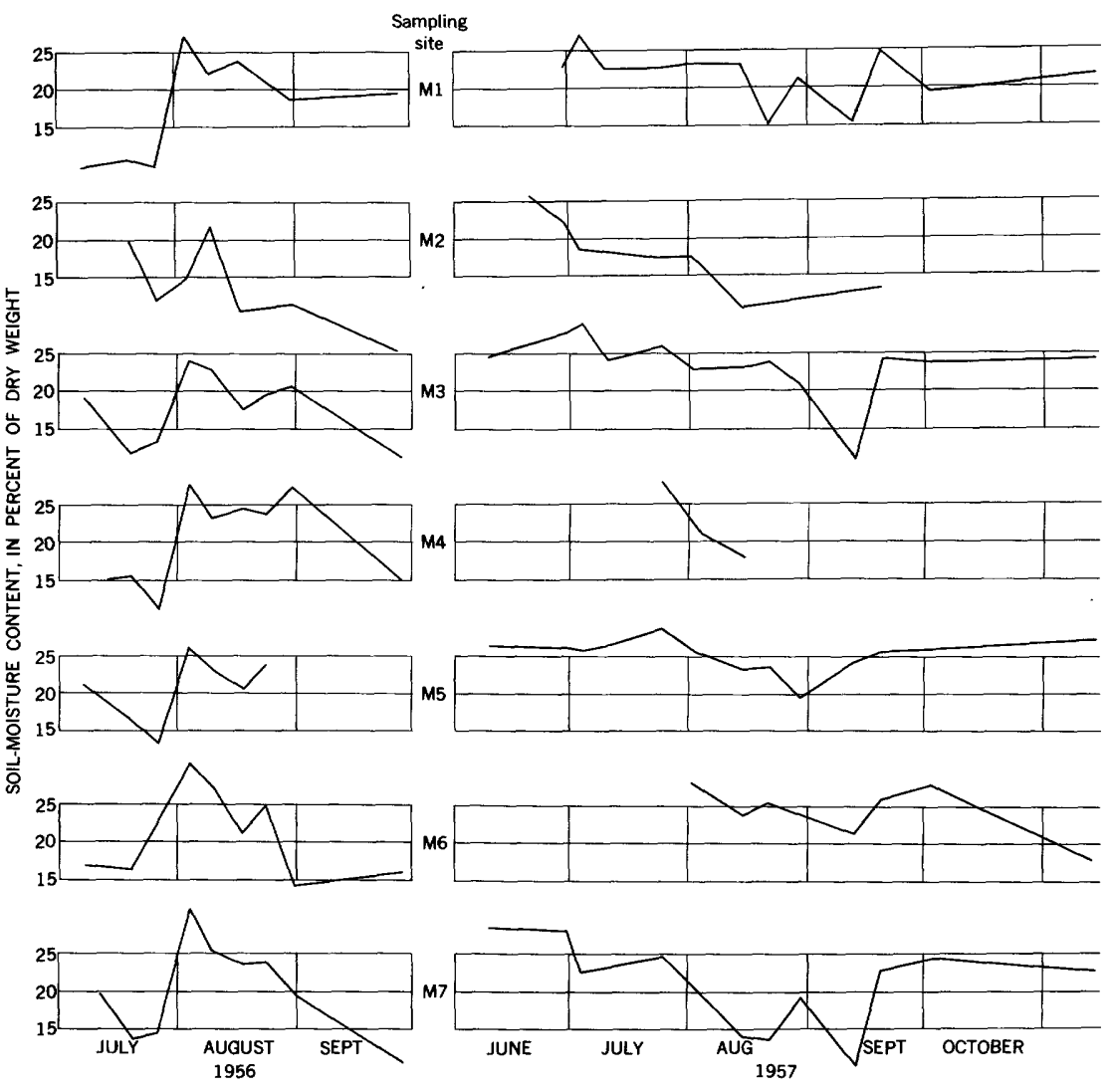

FIGURE 13.-Graphs showing soil-moisture content in the Box Creek water-spreading area at 12-inch sampling depth during the summer seasons 1956-57.

The soil-moisture records show the following general trends:

1. During 1956, soil-moisture content at most sampling points was depleted to the permanent wilting point (see table 4) before the storm of July 29, thereby limiting plant growth. This storm and resultant irrigation wet the soil to an average depth of about 24 inches. Following the storm of July 29 , the moisture content was maintained well above the permanent wilting point until after the last hay cutting in August.

2. Moisture content during the 1957 season was generally high, except for a short period before the storm of September 13. At no time should evapotranspiration or plant growth have been limited because of soil-moisture conditions.

In addition to the soil-moisture sampling program, data were obtained for the preparation of moisture-retention curves for the soils in 
the water-spreading area. These curves define the limits of usable soil moisture and the pore-size characteristics of the soils.

\section{SOIL-MOISTURE RETENTION RELATIONSHIPS}

Moisture-retention curves have been used extensively for irrigation control. They define the limits of soil-moisture content for optimum crop growth. In the present study, they were used to estimate the amount of moisture absorbed on the water-spreading area during a storm.

A moisture-retention curve is a graph showing the relationship between the moisture content of a soil and the tension force with which that moisture is being held by the soil. The force required to remove moisture from a soil pore depends upon the pore size. The volume of water retained in a soil at a given tension is, therefore, related to the total volume of pore spaces that are smaller than a given size. Bradfield (1938) gives the relationship for pore diameters as $d=0.30 / h$, where $d$ is the pore diameter, in centimeters, and $h$ is the tension, in centimeters of water. Thus, a moisture-retention curve also helps to define soil structure.

There are several direct and indirect methods of obtaining the data for soil-moisture retention curves. In the direct methods, samples of the soil are satruated and then subjected to known tension forces to remove moisture. After exposure to a specified tension force for sufficient time to reach equilibrium, a standard moisture content test is run on the sample.

Indirect methods involve the exposure of an inert porous material to the soil until the moisture-tension forces in the soil and the inert material are equalized. A physical property of the inert material that is a function of the moisture content is then measured. For these methods, the inert material must be calibrated in terms of moisture tension versus whatever physical property is measured.

Moisture-retention curves for samples of alluvium from Box Creek were obtained by using filter paper as the inert material in an indirect gravimetric method described by Gardner (1937).

The method was modified to permit the use of partly disturbed field samples with natural moisture instead of prepared samples. Also, thymol was used to inhibit the growth of microorganisms instead of 0.2 percent $\mathrm{HgCl}_{2}$ solution.

The data for moisture-retention curves were obtained from a set of moisture samples taken on November 13, 1957. The soil-moisture tension of this set of samples was measured at four steps in the drying cycle to give four arbitrary points on the moisture-retention curve for each sample. These data are given in table 4. 


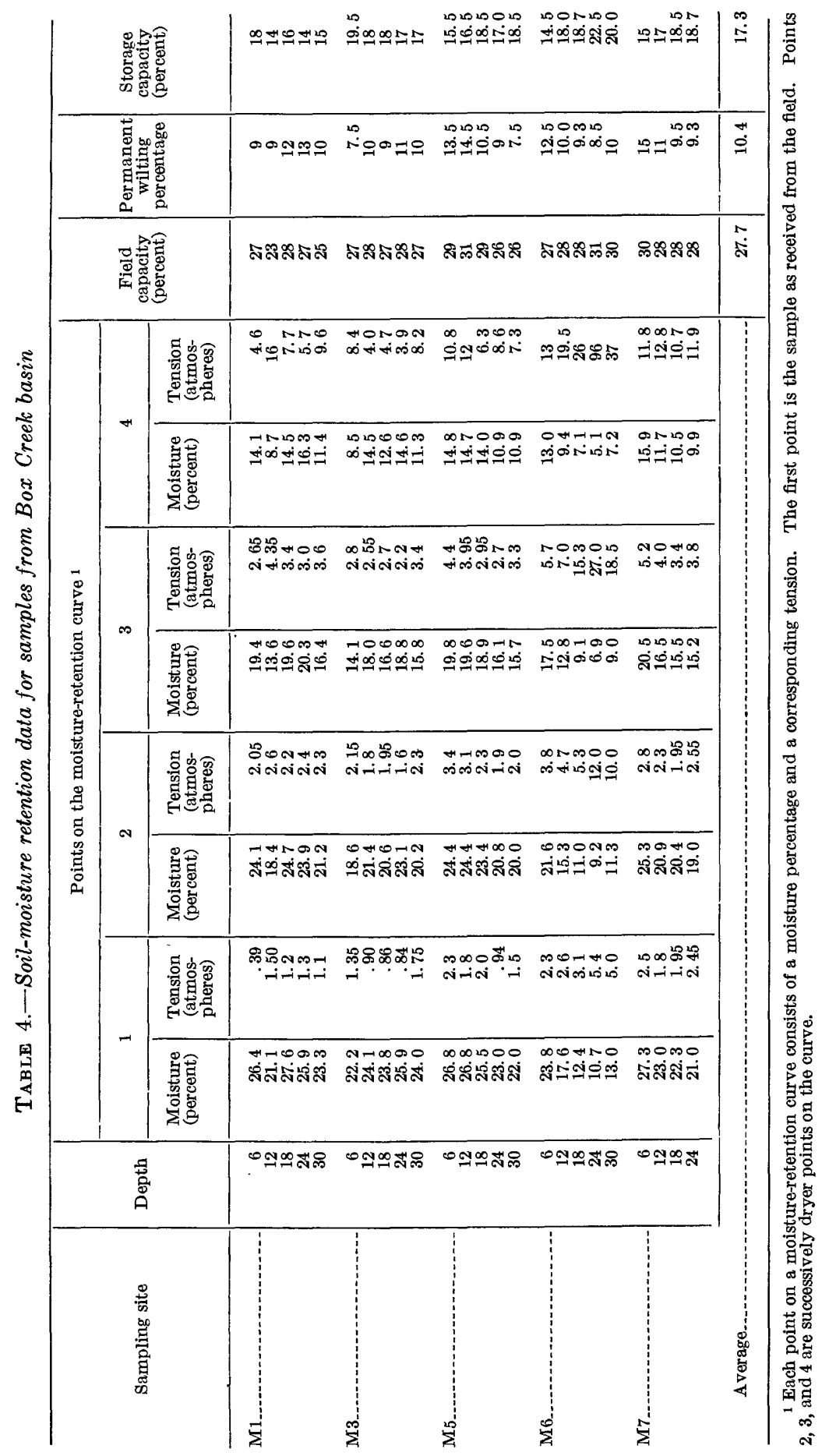




\section{SIGNIFICANCE OF MOISTURE-RETENTION LIMITS}

The lower limit of water available for plant growth is usually considered to be the permanent-wilting percentage. Test plants growing in a sample of soil become permanently wilted when the moisture content of the soil is reduced to this value.

For a wide variety of soils, this permanent-wilting percentage has been found to correspond closely to the amount of water retained at a tension of about 15 atmospheres. It is generally accepted that the moisture content of a soil, when the tension is about 15 atmospheres, is the lower limit of usable soil moisture.

The upper limit of available soil moisture or field capacity has been defined as the amount of water held in the soil after the excess water has drained away by gravity and after the rate of downward movement of water has materially decreased (Lyon, Buckman, and Brady, 1952 , p. 190). This value is determined not only by the properties of the soil but also by the conditions of drainage as influenced by underlying materials and other field conditions. The moisture content at one-third atmosphere tension as determined in the laboratory has been used as a tentative field capacity and then adjusted on the basis of field moisture samples to include the effects of local differences in drainage. Field capacities given in table 4 have been adjusted for field conditions on the basis of 2 years of moisture sampling.

\section{MOISTURE-RETENTION DATA}

Moisture-retention data for selected moisture-sampling sites on the Box Creek water spreader are presented in table 4. Also, the permanent-wilting percentage, the field capacity, and the storage capacity of the soils are given. Moisture-retention curves for sampling site M3 are given in figure 14. The permanent-wilting percentage was obtained from the moisture-retention curves. The field capacity was obtained from the moisture-retention curves and adjusted on the basis of the soil-moisture record. The storage capacity is the difference between the permanent-wilting percentage and the field capacity.

\section{ESTIMATTON OF MOISTURE ABSORPTION}

The average moisture content of the soils on the water spreader, following an extended period of dry weather, may be close to the permanent-wilting percentage. If enough water is contributed by precipitation and waterspreading, the moisture content of the soil will be increased to the field capacity. The depth of this increased moisture content will depend upon the infiltration rate and the time that water is applied.

The moisture records indicate that for storms preceded by low soilmoisture content the average depth of wetting did not exceed 2.5 feet. An increase in the moisture content for this depth from the permanent- 


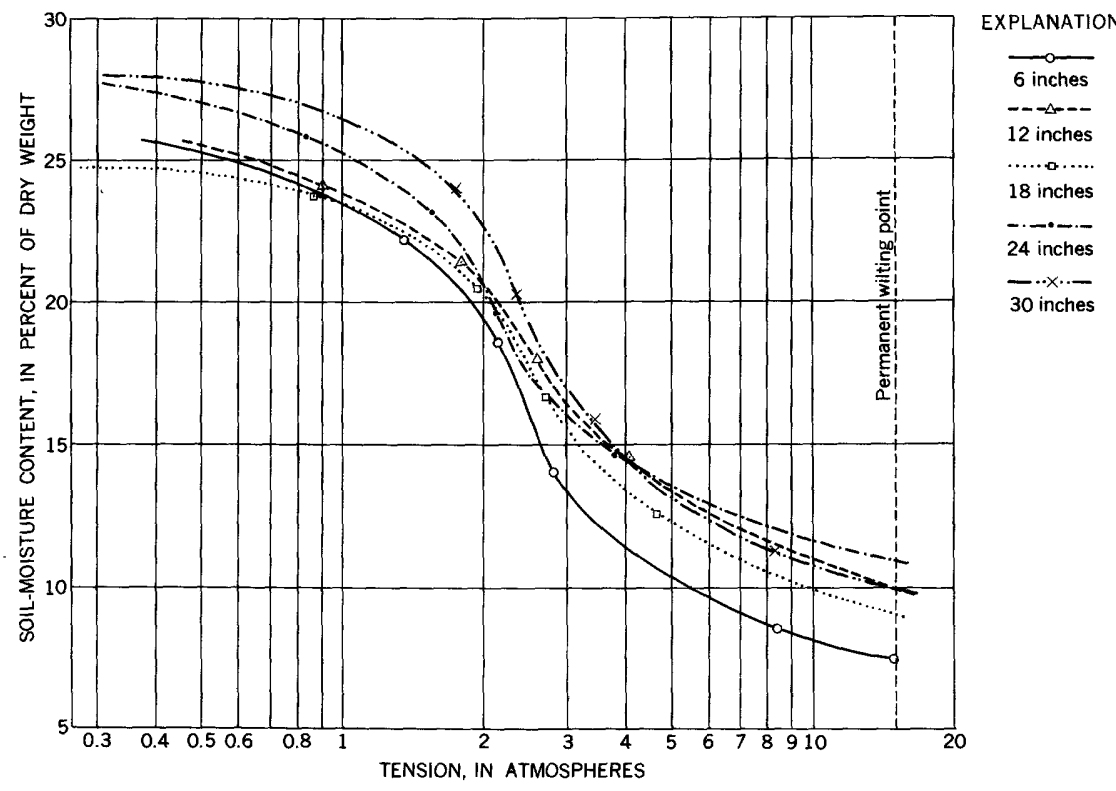

FIGURE 14.-Moisture-retention curves for sampling site M3.

wilting point to the field capacity may be assumed to represent the maximum absorption for a single storm and resultant irrigation. If we assume the dry unit weight of soil at 95 pounds per cubic foot, then the depth to which moisture could be absorbed per foot of wetted soil would be 17.3 percent (the average storage capacity) multiplied by $95 / 62.4 \times 100$ or 0.263 foot. For the 2.5 -foot wetted zone, for an area of 360 acres, the absorption would be as much as 240 acre-feet of water.

By using the average moisture content preceding a storm and comparing it with the field capacity of sediments in the depth at which the moisture content had increased, the absorption by the water spreader was computed for runoff periods as follows: July 29-30, 1956, 200 acre-feet; July 18-20, 1957, 66 acre-feet; September 13-15, 1957, 95 acre-feet. Moisture records were not adequate for periods preceding other storm events to compute moisture absorption.

The retention by the water spreader for the July 29-30, 1956, period computed from inflow, outflow, and precipitation records was 200 acre-feet, which happens to agree exactly with the figure obtained from changes in soil moisture. The agreement is doubtless partly coincidental. The retention by the water spreader for the period September 13-15, 1957, was 121 acre-feet. For the period July $18-20,1957$, it was not possible to compute the precipitation from inflow-outflow computations because of reservoir spill and the 
failure of reservoir 9; therefore, absorption was estimated from moisture records.

The difference between the water spreader retention computed from inflow-outflow data and the moisture absorption computed from moisture records in the period September 13-15, 1957, can be attributed to filling of ponds behind the dikes during the storm. These ponds were empty or nearly empty before the storm.

\section{MOISTURE USE}

The moisture records for 1957 indicate an uncommonly high moisture content through the growing season. Moisture tension did not reach 15 atmospheres (permanent wilting point), so growth should not have been limited at any time by moisture stress. The total evapotranspiration during the growing season was greater than normal because more moisture was available. However, the water spreader did not absorb much moisture from each storm, because the moisturestorage capacity was filled most of the time. The percentage of the available moisture that was used by the water spreader was probably less during 1957 than in earlier years.

\section{INTERPRETATION OF SEDIMENT MEASUREMENTS}

Determining the effectiveness of the Box Creek water spreader in causing the deposition of suspended sediment from storm runoff was one of the primary objectives of the study. Resurveys of six sedimentation ranges and sediment samples taken at both gaging stations during storm periods in 1957 , to determine the suspendedsediment load both in inflow and outflow, furnished some data on the disposition of sediment during the two runoff seasons. Because much of the sediment load and runoff passing the lower gaging station were derived from tributary areas between the upper and lower gaging stations, the measurement of all sediment loads entering the spreading area would have been possible only with an extensive system of automatic samplers. However, the data from resurvey of the sedimentation ranges and from suspended-sediment records for two storm periods in 1957, when there was no runoff from the area between gaging stations, permit some measure of sediment retention on the water spreader.

\section{SEDIMENTATION RANGES}

The six sedimentation ranges are distributed along the entire length of the water spreader and are representative of general conditions on the flood plain. (See fig. 3.)

The ranges were surveyed originally on July 2, 1956, at the beginning of the study. They were resurveyed for the first time at the close of the runoff season on September 24, 1956, and again with the 
termination of the study on November 13, 1957. As would be expected, owing to the small amount of runoff in 1956, the sedimentation ranges showed only slight changes. In 1957 noticeable deposition and erosion were observed on most ranges. The comparative changes in the six ranges revealed by resurveys are shown in figure 15 .

As a means of determining the total sedimentation or erosion in the water-spreading area, differences shown by the surveys in the elevation of individual stations along each range were computed and added algebraically to give a net figure for the overall change on each range. The area between ranges was planimetered from the maps of the water-spreader prepared by the U.S. Bureau of Reclamation on a scale of 1 inch to 200 feet. Assuming that the net depth of erosion or deposition for each pair of ranges was fairly representative of : the intervening area, the volumetric changes in acre-feet were computed. (See table 5.)

During the period July 2 to September 24,1956 , the net deposition on the spreading area was 1.1 acre-feet, and between September 25, 1956, and November 13, 1957, the net deposition was 16.7 acre-feet' Therefore, during the period of study the measured sedimentation was 17.8 acre-feet on the 360 acres included in the water spreader, or an average of 0.049 foot on the area.

\section{SUSPENDED-SEDIMENT MEASUREMENTS}

The suspended-sediment records for the gaging stations were computed for the 1957 runoff season, but direct comparison is meaningless because of the unmeasured load that was contributed from the intervening drainage area. Some generalized interpretations may be made for selected storm periods when there was no runoff from the area between gaging stations. The seasonal totals also show that

TABLE 5.-Sedimentation on Box Creek water spreader from July 2,1956 , to November 13, 1957

\begin{tabular}{|c|c|c|c|c|c|c|}
\hline \multirow{2}{*}{ Sedimentation range } & \multicolumn{2}{|c|}{$\begin{array}{l}\text { A verage depth of ero- } \\
\text { sion }(-) \text { or deposition } \\
(+) \text { during period (foot) }\end{array}$} & \multirow{2}{*}{$\begin{array}{c}\text { Area } \\
\text { between } \\
\text { ranges } \\
\text { (acres) }\end{array}$} & \multicolumn{2}{|c|}{$\begin{array}{l}\text { Volume of erosion }(-) \\
\text { or deposition }(+) \text { dur- } \\
\text { ing period (acre-ft) }\end{array}$} & \multirow{2}{*}{$\begin{array}{l}\text { Net volume } \\
\text { (acre-ft) }\end{array}$} \\
\hline & $\begin{array}{l}\text { July } 2 \text { to } \\
\text { Sept. 24, } \\
\text { 1956 }\end{array}$ & $\begin{array}{c}\text { Sept. 25, } \\
1956 \text { to Nov. } \\
13,1957\end{array}$ & & $\begin{array}{l}\text { July } 2 \text { to } \\
\text { Sept. } 24, \\
1956\end{array}$ & $\begin{array}{l}\text { Sept. } 25 \\
1956, \text { to Nov. } \\
13,1957\end{array}$ & \\
\hline $1 \ldots$ & +0.034 & +0.327 & & & & \\
\hline $2 \ldots$ & -.069 & -.039 & $\begin{array}{l}0.0 \\
74.5\end{array}$ & $\begin{array}{l}-0.0 \\
-2.4\end{array}$ & $\begin{array}{l}-9.0 \\
-9\end{array}$ & $\begin{array}{l}T .1 \\
-3.3\end{array}$ \\
\hline $3 \ldots$ & +.005 & +.014 & $\begin{array}{l}74.5 \\
55.5\end{array}$ & $\begin{array}{r}-2.4 \\
-.6\end{array}$ & $\begin{array}{r}.0 \\
+3.6\end{array}$ & $\begin{array}{r}+3.0 \\
+\end{array}$ \\
\hline 4 & -.027 & +.116 & $\begin{array}{l}50.0 \\
84.6\end{array}$ & $\begin{array}{r}-.0 \\
+1.4\end{array}$ & $\begin{array}{r}0.0 \\
+4.6\end{array}$ & $\begin{array}{r}+6.0 \\
+6.0\end{array}$ \\
\hline $\begin{array}{l}5 \ldots \\
6 \ldots\end{array}$ & $\begin{array}{l}+.059 \\
+.001\end{array}$ & $\begin{array}{l}-.008 \\
+.082\end{array}$ & 110.4 & $\begin{array}{r}+3.3 \\
+3 .\end{array}$ & +4.1 & +7.4 \\
\hline Total_. & & & $\ldots$ & +1.1 & +16.7 & +17.8 \\
\hline
\end{tabular}


WATER SPREAdiNG IN BOX CREeK Basin, WYoming A-33

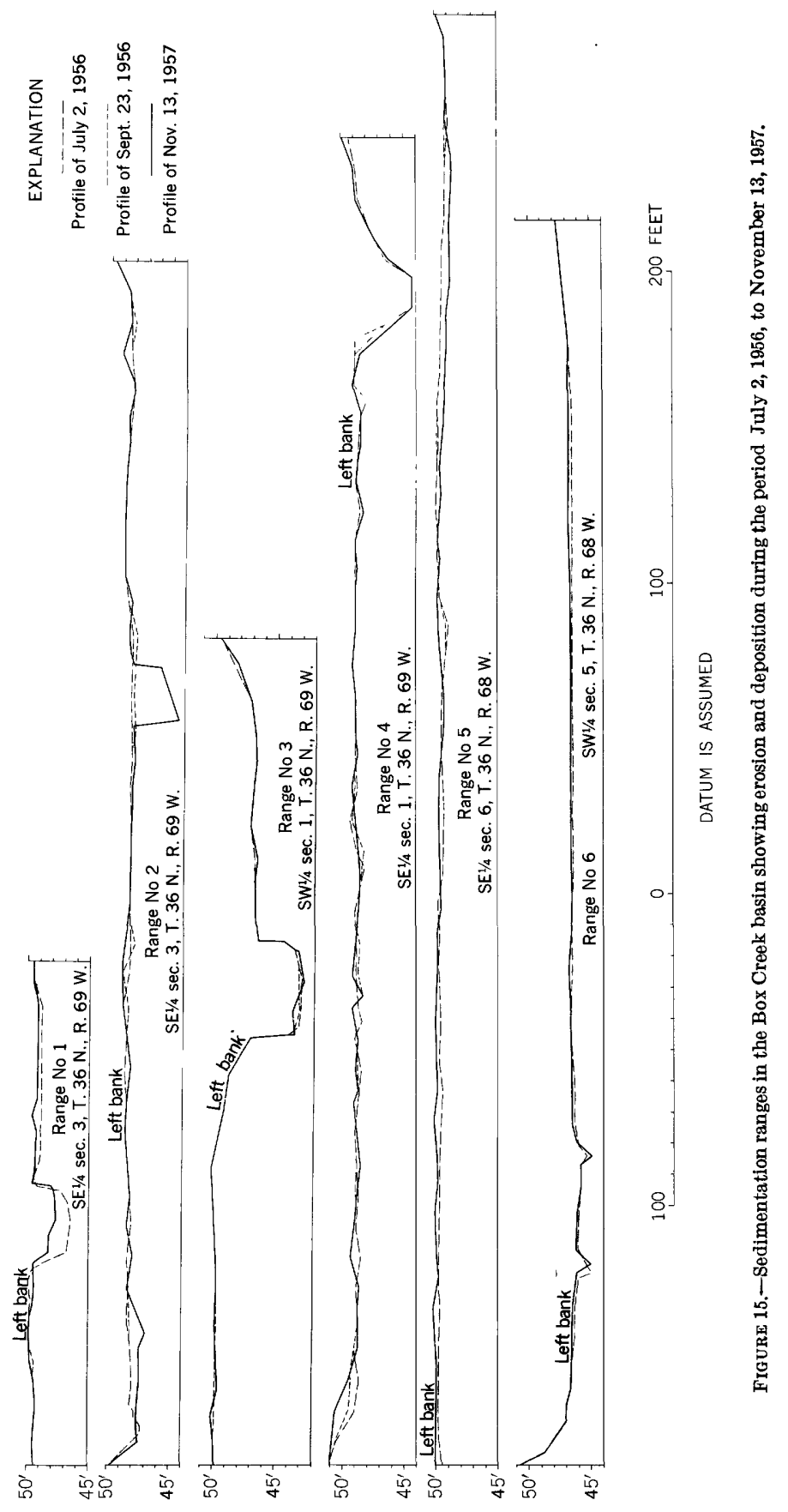


most of the sediment deposited on the water spreader came from the area below the upper gaging station.

During the 1957 season there were two periods in the Box Creek basin when runoff originated in the headwaters above the upper gaging station. The two periods were June 9-14 and June 30 to July 4. The hydrographs showing runoff have been discussed already. In the period June 9-14, the measured suspended-sediment load passing the upper station, Box Creek near Bill, was 2,712 tons, while that at the lower station, Box Creek near mouth, was only 829 tons. (See fig. 16.) Therefore, 1,883 tons was deposited in the channel and on the flood plain between the gages. In the runoff period June 30 to July 4, the suspended-sediment load at the upper station was 1,801 tons, whereas at the lower station it was only 290 tons, representing a depletion by deposition of 75 percent or 1,511 tons. (See fig. 17.) Becuase of the lack of observations in the reach of Box Creek between the upper limit of the water-spreading area and the upper gaging

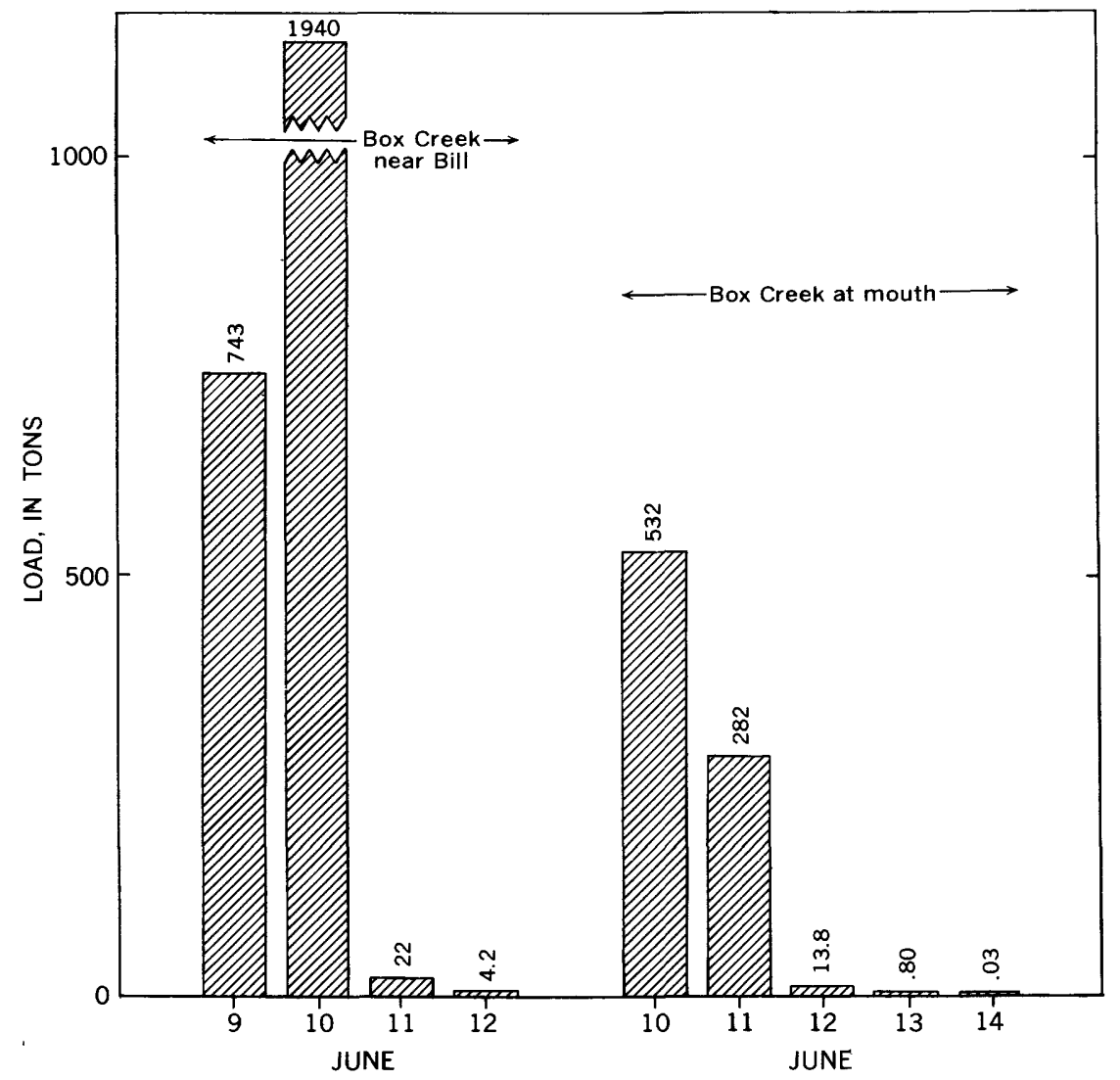

FigURE 16.-Histograms of suspended-sediment load at gaging stations on Box Creek for period June 9-14.' 1957. 


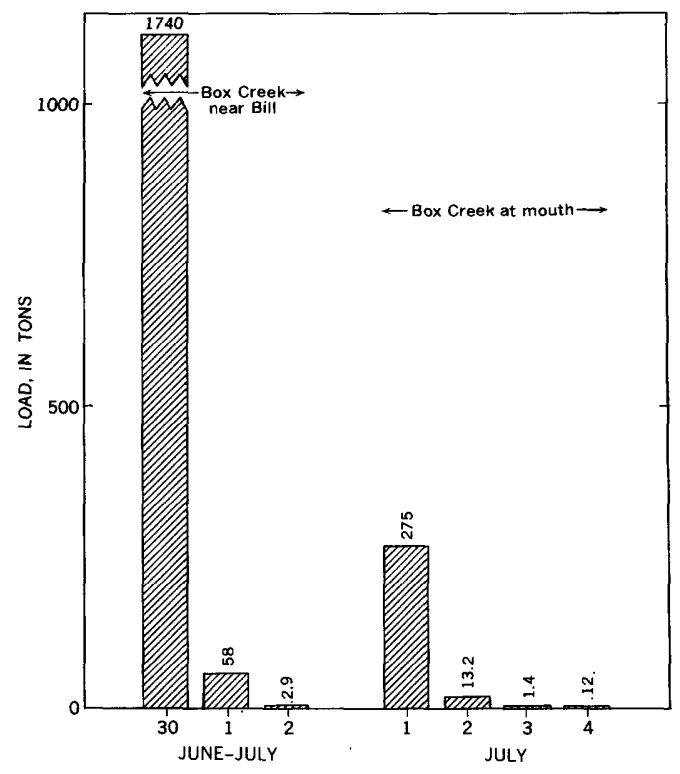

FiguRe 17.-Histograms of suspended-sediment load at gaging stations on Box Creek for period June 30 to July $4,1957$.

station, it was not possible to determine what proportion of the sediment was deposited on the water spreader during these two storms. Therefore, the differences in suspended-sediment load at the two gaging stations represent the depositional losses for the entire intervening area.

The data on suspended-sediment loads measured at Box Creek near Bill and Box Creek at mouth during the period April 9 to October 31, 1957 , are presented on pages $A-36$ and A-37. There was no measurable suspended sediment at the lower station in April, but the estimated suspended-sediment load at the upper station was 1.5 tons. In May, the suspended-sediment load at both stations was considerably higher, because storm runoff occurred on most days after May 13. However, most of the sediment passing the lower gaging station came from the area between the two stations. The suspended-sediment load was 419 tons at the upper station and 3,898 tons at the lower station. The runoff and suspended-sediment load during June was relatively high at the upper station, but there was a large sediment depletion between the upper and lower stations. The suspended load was 4,631 tons at Box Creek near Bill and only 1,029 tons at the mouth. From July 5 to October 31 the suspended-sediment load passing the upper station was insignificant. The load at the lower station, however, resulting from local storms was 2,146 tons on July $18-20$ and 519 tons on September 13-14. 


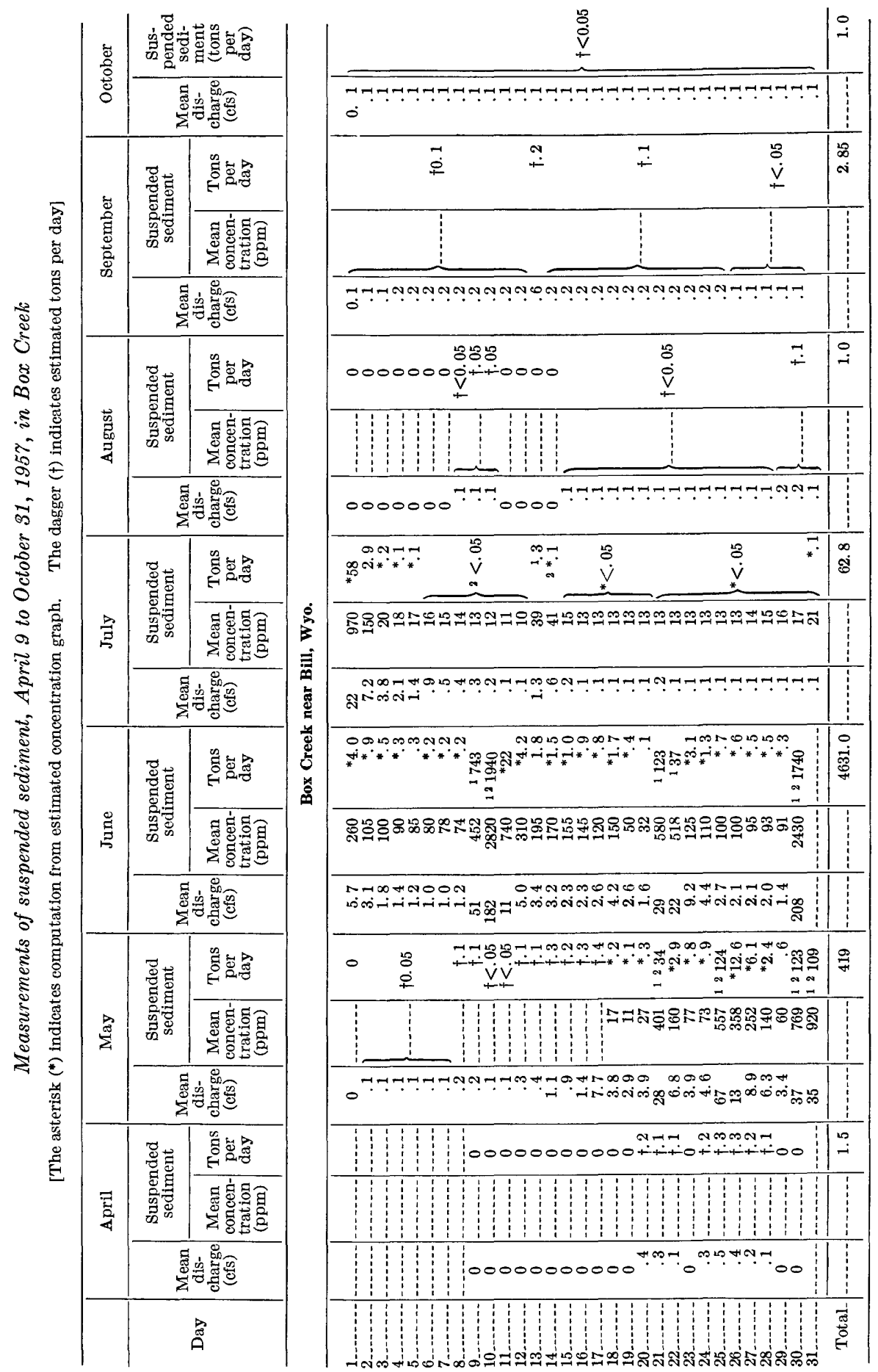


WATER SPREADING IN BOX CREEK BASIN, WYOMING A-37

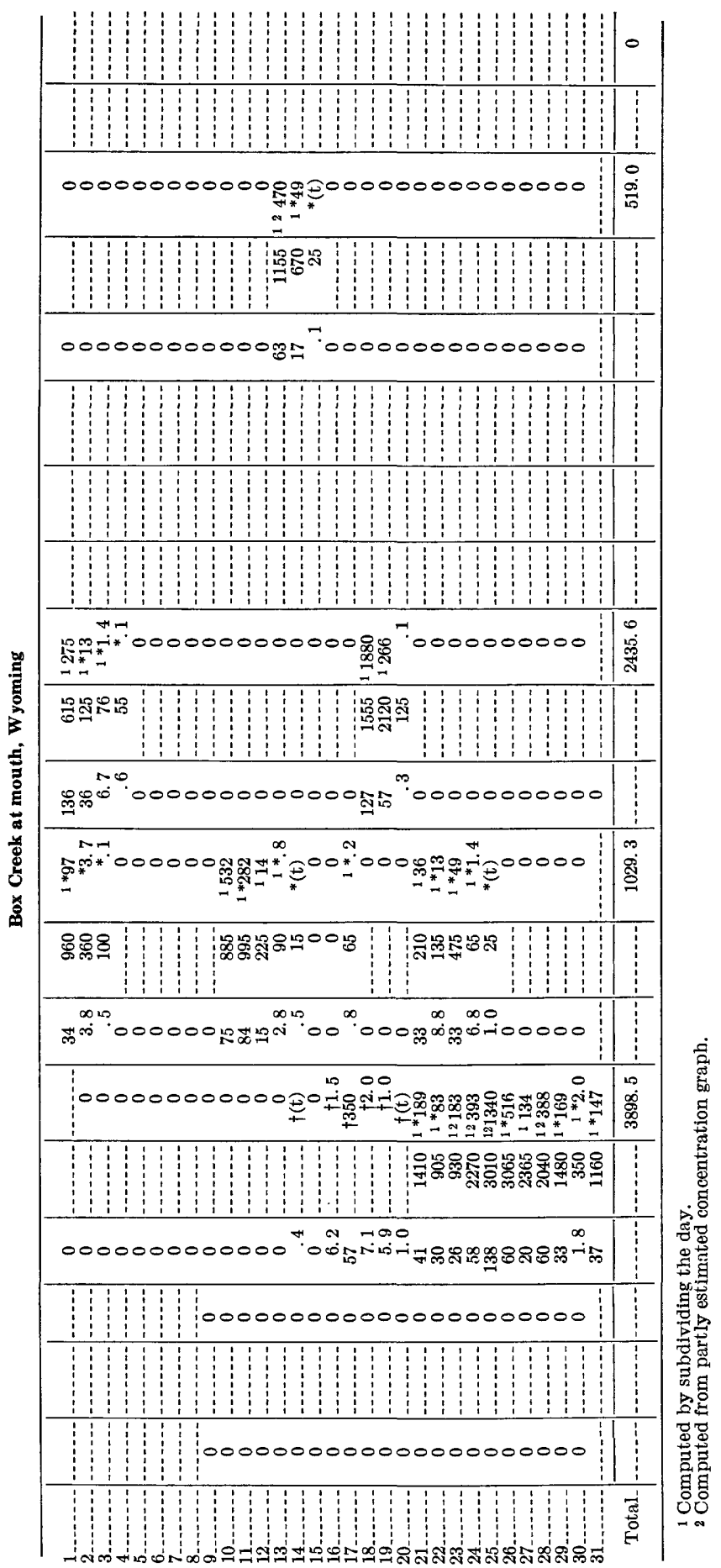


The total suspended-sediment load at the station Box Creek near Bill for the 1957 season (April through September) was 5,118 tons, and for the station Box Creek at mouth it was 7,882 tons. For comparing the suspended-sediment data with the volumetric measurements along the sedimentation ranges, the figures may be converted from tons to acre-feet by using an arbitrary value of 80 pounds per cubic foot, or about 1,742 tons per acre-foot, as the weight of sediment. On this basis, about 2.94 acre-feet of sediment passed the upper gage and 4.52 acre-feet was measured leaving the basin at the mouth during the 1957 season. The resurvey of the sedimentation ranges showed that 16.7 acre-feet of sediment was deposited on the water spreader from September 24, 1956, to November 13, 1957. If all sediment passing the upper gage during that period was trapped in the spreading area, it would only account for about 18 percent of the measured aggradation. Therefore, a major part of the sediment deposited on the water spreader came from the slopes adjacent to the water spreader.

Sediment samples taken during the two periods in 1957, when there was no runoff between the gaging stations, show reductions in the sediment load of 70 and 84 percent. The average concentration of sediments in the water passing through the water spreader during these two runoff periods was reduced 53 and 76 percent.

\section{CONCLUSIONS}

Some general conclusions may be drawn from the hydrologic data gathered during two runoff seasons in the Box Creek area, and the results may be applied in a general way to other areas in the Cheyenne River basin where similar treatment has been proposed. Certain limitations are placed on the interpretations of data that are discussed in this report as to the disposition of runoff and sediment on the Box Creek water spreader. The short period of observation available for the study limited the range of data that could be gathered, and a long-term study might have shown somewhat different results. The nonuniform distribution of observation reservoirs used to map inflow from tributaries between gaging stations resulted in inadequate measurements of runoff for some storms. Because of the difficulty of making observations in the reach of the valley between the upper gaging station and the head of the water spreader, the effect of the water spreader on runoff and sediment retention could not be determined accurately for storms concentrated in the headwaters of Box Creek.

It has been shown in other studies (Culler, 1961; Hadley and Schumm, 1961) that there is a natural depletion of both streamflow and sediment during storm runoff periods in the ephemeral streams 
of the Cheyenne River basin. As might be expected, this loss is increased by diverting flood flows out of the channel and spreading the water over a permeable flood plain having many times the surface area of the channel. However, these data from Box Creek probably cannot be applied directly to other areas where water spreading has been proposed. The Box Creek water spreader has been in operation for about 30 years and the channel has been completely filled in places. Also, repeated flooding of the valley floor has undoubtedly improved growth of vegetation and laid down a considerable deposit of silt and clay that retains moisture better than coarser material. Furthermore, the perched water table in the Box Creek water spreader is shallow, because the valley is not now drained by a deep gully. All these factors contribute to maintaining high moisture contents on the water spreader; consequently, the amount of infiltration in this area is less during storm runoff than that in a newly established water-spreading area. In all the additional areas proposed for treatment, the flood plains are trenched by deep gullies 10 to 15 feet deep. These natural drainage ditches tend to lower the local water table and decrease the soil moisture so that most of the alluvial terrace bordering the channel is deficient in moisture. The vegetation on the valley floor is also sparse because overbank flooding occurs rarely. If a series of diversion dikes are placed across these channels, the absorption of storm runoff is expected to be greater than that observed in Box Creek until the moisture deficiency is overcome. Therefore, the depletion of runoff observed in the study area, despite the large use by vegetation, is probably lower than that which might be anticipated initially in the several proposed areas.

\section{RECORDS}

\section{RUNOFF INTO RESERVATION RESERVOIRS}

Station descriptions for 10 observation reservoirs and the records of runoff for individual runoff periods are given in the following table.

\section{Reservoir I}

Location.-SE1/4SW1/4 sec. 6, T. 36 N., R. 68 W., near Bill, Wyo.

Gage.-Reference mark; crest stages observed; gage read once weekly or oftener. Drainage area.- $0.56 \mathrm{sq} \mathrm{mi}$.

Records available.-1956, summer months only.

Runoff and discharge determinations.-Contents of reservoir and volume of inflow computed from a stage-capacity curve of the reservoir.

Capacity.-3.2 acre-ft at spillway (gage height of $46.1 \mathrm{ft}$ ), August 1956 .

Maximums.-Maximum storm inflow volume 5.84 acre-ft, 10.4 acre-ft per sq mi, July 29, 1956.

Remarks.-Records good, except that those for spill are poor. 
Seasonal storm runoff, 1956

\begin{tabular}{|c|c|c|c|c|c|c|}
\hline \multirow{2}{*}{ Date of flow } & \multicolumn{2}{|c|}{$\begin{array}{l}\text { Water-surface } \\
\text { elevation (ft) }\end{array}$} & \multirow{2}{*}{$\begin{array}{l}\text { Inflow } \\
\text { stored } \\
\text { (acre-ft) }\end{array}$} & \multirow{2}{*}{$\underset{\text { (acre-ft) }}{\text { Spill }}$} & \multirow{2}{*}{$\begin{array}{c}\text { Total } \\
\text { inflow } \\
\text { (acre-ft) }\end{array}$} & \multirow{2}{*}{$\begin{array}{l}\text { Inflow } \\
\text { (acre-ft } \\
\text { per } \\
\text { sq mi) }\end{array}$} \\
\hline & $\begin{array}{l}\text { Before } \\
\text { inflow }\end{array}$ & $\begin{array}{c}\text { After } \\
\text { inflow }\end{array}$ & & & & \\
\hline $\begin{array}{l}\text { July } 16 \\
\text { July } 29 \\
\text { Aug. } 17-\ldots 56 \\
\text { Aug. } 20 \\
\text { Sept. } 10\end{array}$ & $\begin{array}{l}43.4 \\
43.7 \\
45.4 \\
45.4 \\
44.9\end{array}$ & $\begin{array}{l}44.1 \\
46.1 \\
45.5 \\
45.5 \\
45.0\end{array}$ & $\begin{array}{l}0.44 \\
2.16 \\
.10 \\
.10 \\
.08\end{array}$ & $\begin{array}{l}0 \\
3.68 \\
0 \\
0 \\
0\end{array}$ & $\begin{array}{r}0.44 \\
5.84 \\
.10 \\
.10 \\
.08\end{array}$ & $\begin{array}{r}0.8 \\
10.4 \\
.2 \\
.2 \\
.1\end{array}$ \\
\hline
\end{tabular}

\section{Reservoir 2}

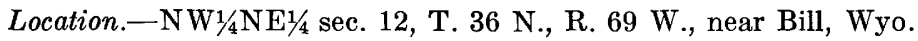

Gage.--Reference mark; crest stages observed; gage read once weekly or oftener.

Drainage area.-- $0.39 \mathrm{sq} \mathrm{mi}$.

Records available.-1956-57, summer months only.

Runoff and discharge determinations.-Contents of reservoir and volume of inflow computed from a stage-capacity curve of the reservoir.

Capacity.-12.0 acre-ft at spillway (gage height of $46.1 \mathrm{ft}$ ), August 1956 .

Maximums.-Maximum storm inflow volume 8.1 acre- $\mathrm{ft}, 20.8$ acre-ft per sq mi,

July 29, 1956.

Remarks.-Records good.

Seasonal storm runoff, 1956-57

\begin{tabular}{|c|c|c|c|c|c|c|}
\hline \multirow{2}{*}{ Date of flow } & \multicolumn{2}{|c|}{$\begin{array}{l}\text { Water-surface } \\
\text { elevation (ft) }\end{array}$} & \multirow{2}{*}{$\begin{array}{l}\text { Inflow } \\
\text { stored } \\
\text { (acre-ft) }\end{array}$} & \multirow{2}{*}{$\underset{\text { (acre-ft) }}{\text { Spill }}$} & \multirow{2}{*}{$\begin{array}{l}\text { Total } \\
\text { inflow } \\
\text { (acre-ft) }\end{array}$} & \multirow{2}{*}{$\begin{array}{l}\text { Inflow } \\
\text { (acre-ft } \\
\text { per } \\
\text { sq mi) }\end{array}$} \\
\hline & $\begin{array}{l}\text { Before } \\
\text { inflow }\end{array}$ & $\begin{array}{l}\text { After } \\
\text { inflow }\end{array}$ & & & & \\
\hline $\begin{array}{l}\text { July } 16 \\
\text { July } 29\end{array}$ & $\begin{array}{l}41.20 \\
41.30\end{array}$ & $\begin{array}{l}41.60 \\
45.20\end{array}$ & $\begin{array}{l}0.5 \\
8.1\end{array}$ & $\begin{array}{l}0 \\
0\end{array}$ & $\begin{array}{l}0.5 \\
8.1\end{array}$ & $\begin{array}{r}1.3 \\
20.8\end{array}$ \\
\hline 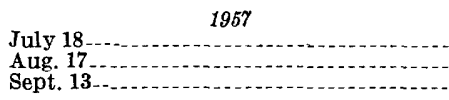 & $\begin{array}{l}42.35 \\
43.30 \\
42.60\end{array}$ & $\begin{array}{l}45.00 \\
43.70 \\
43.95\end{array}$ & $\begin{array}{r}5.9 \\
.9 \\
2.8\end{array}$ & $\begin{array}{l}0 \\
0 \\
0\end{array}$ & $\begin{array}{r}5.9 \\
.9 \\
2.8\end{array}$ & $\begin{array}{r}15.1 \\
2.1 \\
7.4\end{array}$ \\
\hline
\end{tabular}

\section{Reservoir 3}

Location.-SW1/4SW1/4 sec. 36 , T. 37 N., R. 69 W., near Bill, Wyo.

Gage.-Reference mark; crest stages observed; gage read once weekly or oftener.

Drainage area.- $0.53 \mathrm{sq} \mathrm{mi}$.

Records available.-1956-57, summer months only.

Runoff and discharge determinations.-Contents of reservoir and volume of inflow computed from a stage-capacity curve of the reservoir.

Capacity.-25.0 acre-ft at spillway (gage height of $47.3 \mathrm{ft}$ ), August 1956.

Maximums.--Maximum storm inflow volume 14.0 acre-ft, 26.4 acre-ft per sq mi, July 18, 1957.

Remarks.-Records good. 
Seasonal storm runoff, $1956-57$

\begin{tabular}{|c|c|c|c|c|c|c|}
\hline \multirow{2}{*}{ Date of flow } & \multicolumn{2}{|c|}{$\begin{array}{l}\text { Water-surface } \\
\text { elevation (ft) }\end{array}$} & \multirow{2}{*}{$\begin{array}{l}\text { Inflow } \\
\text { stored } \\
\text { (acre-ft) }\end{array}$} & \multirow{2}{*}{$\underset{\text { (acre-ft) }}{\text { Spill }}$} & \multirow{2}{*}{$\begin{array}{l}\text { Total } \\
\text { inflow } \\
\text { (acre-ft) }\end{array}$} & \multirow{2}{*}{$\begin{array}{l}\text { Inflow } \\
\text { (acre-ft } \\
\text { per } \\
\text { sq mi) }\end{array}$} \\
\hline & $\begin{array}{l}\text { Before } \\
\text { inflow }\end{array}$ & $\begin{array}{l}\text { After } \\
\text { inflow }\end{array}$ & & & & \\
\hline $\begin{array}{l}\text { July } 16 \\
\text { July } 29\end{array}$ & $\begin{array}{l}35.10 \\
35.00\end{array}$ & $\begin{array}{l}36.40 \\
41.90\end{array}$ & $\begin{array}{l}0.7 \\
7.5\end{array}$ & $\begin{array}{l}0 \\
0\end{array}$ & $\begin{array}{l}0.7 \\
7.5\end{array}$ & $\begin{array}{r}1.3 \\
14.2\end{array}$ \\
\hline 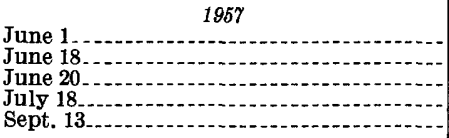 & $\begin{array}{l}44.75 \\
44.20 \\
44.90 \\
43.00 \\
41.95\end{array}$ & $\begin{array}{l}46.10 \\
45.10 \\
45.80 \\
47.05 \\
45.60\end{array}$ & $\begin{array}{r}5.0 \\
3.0 \\
3.5 \\
14.0 \\
10.4\end{array}$ & $\begin{array}{l}0 \\
0 \\
0 \\
0 \\
0\end{array}$ & $\begin{array}{r}5.0 \\
3.0 \\
3.5 \\
14.0 \\
10.4\end{array}$ & $\begin{array}{r}9.4 \\
5.7 \\
6.6 \\
26.4 \\
19.6\end{array}$ \\
\hline
\end{tabular}

\section{Reservoir 4}

Location.-NE $1 / 4$ NW1/4 sec 1, T. 36 N., R. 69 W., near Bill, Wyo.

Gage.-Reference mark; crest stages observed; gage read once weekly or oftener. Drainage area. $-0.14 \mathrm{sq} \mathrm{mi}$.

Records available.-1956-57, summer months only.

Runoff and discharge determinations.-Contents of reservoir and volume of inflow computed from a stage-capacity curve of the reservoir.

Capacity.-2.0 acre-ft at spillway (gage height of $45.0 \mathrm{ft}$ ), August 1956 .

Maximums.-Maximum storm inflow volume 3.85 acre- $\mathrm{ft}$. 22.6 acre-ft per sq mi, July 29, 1956.

Remarks.-Records good, except that those for spill are poor.

Seasonal storm runoff, $1956-57$

\begin{tabular}{|c|c|c|c|c|c|c|}
\hline \multirow{2}{*}{ Date of flow } & \multicolumn{2}{|c|}{$\begin{array}{l}\text { Water-surface } \\
\text { elevation (ft) }\end{array}$} & \multirow{2}{*}{$\begin{array}{l}\text { Inflow } \\
\text { stored } \\
\text { (acre-ft) }\end{array}$} & \multirow{2}{*}{$\underset{\text { (acre-ft) }}{\text { Spill }}$} & \multirow{2}{*}{$\begin{array}{l}\text { Total } \\
\text { inflow } \\
\text { (acre-ft) }\end{array}$} & \multirow{2}{*}{$\begin{array}{l}\text { Inflow } \\
\text { (acre-ft } \\
\text { per } \\
\text { sq mi) }\end{array}$} \\
\hline & $\begin{array}{l}\text { Before } \\
\text { inflow }\end{array}$ & $\begin{array}{l}\text { After } \\
\text { inflow }\end{array}$ & & & & \\
\hline $\begin{array}{l}\text { July } 16 \\
\text { July } 29 \\
\text { July }\end{array}$ & $\begin{array}{l}43.30 \\
43.20\end{array}$ & $\begin{array}{l}43.60 \\
45.00\end{array}$ & $\begin{array}{l}0.18 \\
1.31\end{array}$ & $\begin{array}{l}0 \\
2.54\end{array}$ & $\begin{array}{l}0.18 \\
3.85\end{array}$ & $\begin{array}{r}1.1 \\
22.6\end{array}$ \\
\hline $\begin{array}{l}\text { June } 20 \\
\text { Jun } \\
\text { July } 18 \\
\text { Sept. } 13.057\end{array}$ & $\begin{array}{l}44.70 \\
44.15 \\
43.55\end{array}$ & $\begin{array}{l}45.00 \\
45.00 \\
45.00\end{array}$ & $\begin{array}{r}.28 \\
.72 \\
1.10\end{array}$ & $\begin{array}{l}.16 \\
.96 \\
.15\end{array}$ & $\begin{array}{l}.44 \\
1.68 \\
1.25\end{array}$ & $\begin{array}{l}2.59 \\
9.89 \\
7.36\end{array}$ \\
\hline
\end{tabular}

\section{Reservoir 5}

Location.-SE $1 / 4 \mathrm{SE} 1 / 4$ sec. 36 , T. 37 N., R. 69 W., near Bill, Wyo.

Gage.-Reference mark; crest stages observed; gage read once weekly or oftener. Drainage area. $-0.72 \mathrm{sq} \mathrm{mi}$.

Records available.--1956-57 summer months only.

Runoff and discharge determinations.-Contents of reservoir and volume of inflow computed from a stage-capacity curve of the reservoir.

Capacity.-19.6 acre-ft at spillway (gage height of $46.5 \mathrm{ft}$ ), August 1956 .

Maximums.-Maximum storm inflow volume 9.0 acre-ft, 12.5 acre-ft per sw mi, July 29, 1956.

Remarks.-Records good, except that those for spill are poor. 
Seasonal storm runoff, 1956-57

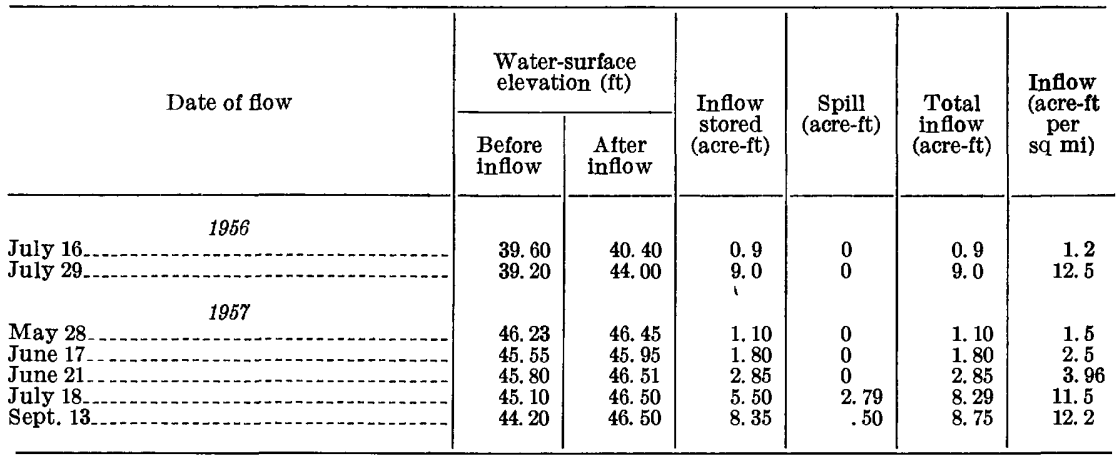

\section{Reservoir 6}

Location.- NW1/4 NW1/4 sec. 6, T. 36 N., R. 68 W., near Bill, Wyo.

Gage.-Reference mark; crest stages observed; gage read once weekly or oftener. Drainage area. $-0.17 \mathrm{sq} \mathrm{mi}$.

Records available.-1956-57, summer months only.

Runoff and discharge determinations.-Contents of reservoir and volume of inflow computed from a stage-capacity curve of the reservoir.

Capacity.-7.0 acre-ft at spillway (gage height $48.4 \mathrm{ft}$ ), August 1956 .

Maximums.-Maximum storm inflow volume 5.41 acre-ft, 31.8 acre-ft per sq mi, July 18, 1957.

Remarks.-Records good, except that those for spill are poor.

Seasonal storm runoff, 1956-57

\begin{tabular}{|c|c|c|c|c|c|c|}
\hline \multirow{2}{*}{ Date of flow } & \multicolumn{2}{|c|}{$\begin{array}{l}\text { Water-surface } \\
\text { elevation (ft) }\end{array}$} & \multirow{2}{*}{$\begin{array}{l}\text { Inflow } \\
\text { stored } \\
\text { (acre-ft) }\end{array}$} & \multirow{2}{*}{ (acre-ft) } & \multirow{2}{*}{$\begin{array}{l}\text { Total } \\
\text { inflow } \\
\text { (acre-ft) }\end{array}$} & \multirow{2}{*}{$\begin{array}{l}\text { Inflow } \\
\text { (acre-ft } \\
\text { per } \\
\text { sq mi) }\end{array}$} \\
\hline & $\begin{array}{l}\text { Before } \\
\text { inflow }\end{array}$ & $\begin{array}{l}\text { After } \\
\text { inflow }\end{array}$ & & & & \\
\hline July 29 & 42.80 & 47.50 & 4. 72 & 0 & 4. 72 & 27.8 \\
\hline $\begin{array}{l}\text { May } 28 \ldots 57 \\
\text { June } 1 . \ldots . . .19 \\
\text { July } 18 \\
\text { Sept. 13 }\end{array}$ & $\begin{array}{l}47.10 \\
47.15 \\
47.50 \\
47.40\end{array}$ & $\begin{array}{l}47.25 \\
48.25 \\
48.40 \\
47.90\end{array}$ & $\begin{array}{l}0.25 \\
2.10 \\
1.75 \\
.9\end{array}$ & $\begin{array}{l}0 \\
0 \\
3.66 \\
0\end{array}$ & $\begin{array}{l}0.25 \\
2.10 \\
5.41 \\
.9\end{array}$ & $\begin{array}{r}1.47 \\
12.4 \\
31.8 \\
5.3\end{array}$ \\
\hline
\end{tabular}

\section{Reservoir 7}

Location.-NE $1 / 4 \mathrm{SE}^{1 / 4}$ sec. 31 , T. 37 N., R. 68 W., near Bill, Wyo.

Gage.-Reference mark; crest stages observed; gage read once weekly or oftener.

Drainage area. $-0.17 \mathrm{sq} \mathrm{mi}$.

Records available.-1956-57, summer months only.

Runoff and discharge determinations. - Contents of reservoir and volume of inflow computed from a stage-capacity curve of the reservoir.

Capacity.-4.4 acre-ft at spillway (gage height $47.78 \mathrm{ft}$ ), August 1956.

Maximums.-Maximum storm inflow volume 4.50 acre-ft, 16.1 acre-ft per sq mi, July 29, 1956.

Remarks.-Records good, except that those for spill are poor. 
WATER SPREADING IN BOX CREEK BASIN, WYOMING A-43

Seasonal storm runoff, 1956-57

\begin{tabular}{|c|c|c|c|c|c|c|}
\hline \multirow{2}{*}{ Date of flow } & \multicolumn{2}{|c|}{$\begin{array}{l}\text { Water-surface } \\
\text { elevation (ft) }\end{array}$} & \multirow{2}{*}{$\begin{array}{l}\text { Inflow } \\
\text { stored } \\
\text { (acre-ft) }\end{array}$} & \multirow{2}{*}{$\underset{\text { (acre-ft) }}{\text { Spill }}$} & \multirow{2}{*}{$\begin{array}{l}\text { Total } \\
\text { inflow } \\
\text { (acre-ft) }\end{array}$} & \multirow{2}{*}{$\begin{array}{l}\text { Inflow } \\
\text { (acre-ft } \\
\text { per } \\
\text { sq mi) }\end{array}$} \\
\hline & $\begin{array}{l}\text { Before } \\
\text { inflow }\end{array}$ & $\begin{array}{l}\text { After } \\
\text { inflow }\end{array}$ & & & & \\
\hline $\begin{array}{c}\text { July } 23 \\
\text { July } 29\end{array}$ & $\begin{array}{l}46.20 \\
46.40\end{array}$ & $\begin{array}{l}46.50 \\
47.70\end{array}$ & $\begin{array}{l}0.35 \\
1.85\end{array}$ & $\begin{array}{l}0 \\
2.65\end{array}$ & $\begin{array}{l}0.35 \\
4.50\end{array}$ & $\begin{array}{r}1.2 \\
16.1\end{array}$ \\
\hline $\begin{array}{l}\text { May } 28 \text { 1957 } \\
\text { June } 17 \\
\text { June } 21 \\
\text { July } 18 \\
\text { Sept. } 13.0 .\end{array}$ & $\begin{array}{l}47.75 \\
47.15 \\
47.60 \\
47.15 \\
46.65\end{array}$ & $\begin{array}{l}47.78 \\
47.75 \\
47.78 \\
47.78 \\
47.35\end{array}$ & $\begin{array}{r}.05 \\
.95 \\
.30 \\
1.0 \\
.95\end{array}$ & $\begin{array}{l}2.90 \\
0 \\
0 \\
0^{.40}\end{array}$ & $\begin{array}{r}2.95 \\
.95 \\
.30 \\
1.40 \\
.95\end{array}$ & $\begin{array}{r}10.5 \\
3.4 \\
1.1 \\
5.0 \\
3.4\end{array}$ \\
\hline
\end{tabular}

\section{Reservoir 8}

Location.-NE $14 \mathrm{NW}^{1} / 4$ sec. 5, T. 36 N., R. 68 W., near Bill, Wyo.

Gage.-Reference mark; crest stages observed; gage read once weekly or oftener. Drainage area.- $0.40 \mathrm{sq} \mathrm{mi}$.

Records available.-1957, summer months only.

Runoff and discharge determinations.-Contents of reservoir and volume of inflow computed from a stage-capacity curve of the reservoir.

Capacity.-3.3 acre-ft at spillway (gage height $48.50 \mathrm{ft}$ ), August 1956.

Maximums.-Maximum storm inflow volume 2.14 acre-ft, 5.35 acre-ft per sq mi, July 18, 1957.

Remarks.-Records good, except that those for spill are poor.

Seasonal storm runoff, 1957

\begin{tabular}{|c|c|c|c|c|c|c|}
\hline \multirow{2}{*}{ Date of flow } & \multicolumn{2}{|c|}{$\begin{array}{l}\text { Water-surface } \\
\text { elevation (ft) }\end{array}$} & \multirow{2}{*}{$\begin{array}{l}\text { Inflow } \\
\text { stored } \\
\text { (acre-ft) }\end{array}$} & \multirow{2}{*}{$\underset{\text { (acre-ft) }}{\text { Spill }}$} & \multirow{2}{*}{$\begin{array}{l}\text { Total } \\
\text { inflow } \\
\text { (acre-ft) }\end{array}$} & \multirow{2}{*}{$\begin{array}{c}\text { Inflow } \\
\text { (acre-ft } \\
\text { per } \\
\text { sq mi) }\end{array}$} \\
\hline & $\begin{array}{l}\text { Before } \\
\text { inflow }\end{array}$ & $\begin{array}{l}\text { After } \\
\text { inflow }\end{array}$ & & & & \\
\hline $\begin{array}{l}\text { July } 18, \ldots 57 \\
\text { Sept. } 13.19\end{array}$ & $\begin{array}{l}47.72 \\
47.54\end{array}$ & $\begin{array}{l}48.50 \\
48.15\end{array}$ & $\begin{array}{r}0.93 \\
.77\end{array}$ & $\begin{array}{l}1.21 \\
0\end{array}$ & $\begin{array}{r}2.14 \\
.77\end{array}$ & $\begin{array}{l}5.35 \\
1.92\end{array}$ \\
\hline
\end{tabular}

\section{Reservoir 9}

Location.-SW1/4 NE1/4 sec. 6, T. 36 N., R. 68 W., near Bill, Wyo.

Gage.-Reference mark, crest stages observed; gage read once weekly or oftener.

Drainage area.- $-2.47 \mathrm{sq} \mathrm{mi}$.

Records available.-1957, June to July only.

Runoff and discharge determinations.-Contents of reservoir and volume of inflow computed from stage-capacity curve of the reservoir.

Capacity.-125.0 acre-ft at spillway (gage height $50.60 \mathrm{ft}$ ), November 1957.

Maximums.-Maximum storm inflow volume 101.5 acre-ft, 41.0 acre-ft per sq mi, July 18, 1957, dam breached.

Remarks.-Records good. 
Seasonal storm runoff, 1957

\begin{tabular}{|c|c|c|c|c|c|c|}
\hline \multirow{2}{*}{ Date of flow } & \multicolumn{2}{|c|}{$\begin{array}{l}\text { Water-surface } \\
\text { elevation (ft) }\end{array}$} & \multirow{2}{*}{$\begin{array}{l}\text { Inflow } \\
\text { stored } \\
\text { (acre-ft) }\end{array}$} & \multirow{2}{*}{$\begin{array}{c}\text { Spill } \\
\text { (acre-ft) }\end{array}$} & \multirow{2}{*}{$\begin{array}{c}\text { Total } \\
\text { inflow } \\
\text { (acre-ft) }\end{array}$} & \multirow{2}{*}{$\begin{array}{l}\text { Inflow } \\
\text { (acre-ft } \\
\text { per } \\
\text { sq mi) }\end{array}$} \\
\hline & $\begin{array}{l}\text { Before } \\
\text { inflow }\end{array}$ & $\begin{array}{c}\text { After } \\
\text { inflow }\end{array}$ & & & & \\
\hline July 18 & 42.25 & 50.50 & 1101.49 & 0 & 101.49 & 41.0 \\
\hline
\end{tabular}

1 Dam breached July 18, 1957 after storm.

\section{Reservoir 41}

Location.-NE $1 / 4 \mathrm{SE}_{1 / 4}^{1 / 4}$ sec. 21, T. 36 N., R. 70 W., near Bill, Wyo.

Gage.-Reference mark; crest stages observed; gage read once weekly or oftener.

Drainage area.-1.26 sq mi.

Records available.-1956-57, summer months only.

Runoff and discharge determinations.-Contents of reservoir and volume of inflow computed from a stage-capacity curve of the reservoir.

Capacity.-6.9 acre-ft at spillway (gage height $29.0 \mathrm{ft}$ ), August 1956.

Maximums.-Maximum storm inflow volume 2.05 acre-ft, 1.63 acre-ft per sq mi, June 9, 1957.

Remarks.-Records good.

Seasonal storm runoff, $1956-57$

\begin{tabular}{|c|c|c|c|c|c|c|}
\hline \multirow{2}{*}{ Date of flow } & \multicolumn{2}{|c|}{$\begin{array}{l}\text { Water-surface } \\
\text { elevation (ft) }\end{array}$} & \multirow{2}{*}{$\begin{array}{l}\text { Inflow } \\
\text { stored } \\
\text { (acre-ft) }\end{array}$} & \multirow{2}{*}{$\underset{\text { (acre-ft) }}{\text { Spill }}$} & \multirow{2}{*}{$\begin{array}{c}\text { Total } \\
\text { inflow } \\
\text { (acre-ft) }\end{array}$} & \multirow{2}{*}{$\begin{array}{l}\text { Inflow } \\
\text { (acre-ft } \\
\text { per } \\
\text { sq mi) }\end{array}$} \\
\hline & $\begin{array}{l}\text { Before } \\
\text { inflow }\end{array}$ & $\begin{array}{c}\text { After } \\
\text { inflow }\end{array}$ & & & & \\
\hline $\begin{array}{l}\text { July } 13 \\
\text { Jept. } 10 \\
\text { Sept }\end{array}$ & $\begin{array}{l}23.20 \\
22.05\end{array}$ & $\begin{array}{l}23.50 \\
22.30\end{array}$ & $\begin{array}{l}0.02 \\
.064\end{array}$ & $\begin{array}{l}0 \\
0\end{array}$ & $\begin{array}{l}0.02 \\
.064\end{array}$ & $\begin{array}{l}0.016 \\
.05\end{array}$ \\
\hline $\begin{array}{l}\text { June } 9 \\
\text { July } 18 \\
\text { Sept. } 13\end{array}$ & $\begin{array}{l}26.65 \\
27.25 \\
26.65\end{array}$ & $\begin{array}{l}28.22 \\
27.80 \\
27.55\end{array}$ & $\begin{array}{r}2.05 \\
.72 \\
1.10\end{array}$ & $\begin{array}{l}0 \\
0 \\
0\end{array}$ & $\begin{array}{r}2.05 \\
.72 \\
1.10\end{array}$ & $\begin{array}{r}1.63 \\
.57 \\
.87\end{array}$ \\
\hline
\end{tabular}

\section{SOIL-MOISTURE OBSERVATIONS}

Data on the fluctuation of soil moisture are given in the table below for seven sampling sites in the Box Creek water spreader.

\section{Soil-moisture observations}

[Location of sampling sites shown on figure 3]

\begin{tabular}{|c|c|c|c|c|c|c|c|c|}
\hline \multirow{2}{*}{ Date of sampling } & \multirow{2}{*}{$\begin{array}{c}\text { Depth } \\
\text { (inches) }\end{array}$} & \multicolumn{7}{|c|}{$\begin{array}{l}\text { Soil moisture as percent of dry weight for indicated } \\
\text { sampling site }\end{array}$} \\
\hline & & M1 & M2 & M3 & M4 & M5 & M6 & M7 \\
\hline July $7 \ldots$ & $\begin{array}{r}6 \\
12 \\
24 \\
30\end{array}$ & $\begin{array}{r}11.3 \\
9.6 \\
15.8 \\
\end{array}$ & 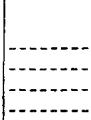 & $\begin{array}{r}9.2 \\
19.2 \\
21.2 \\
\end{array}$ & (n) & $\begin{array}{r}18.2 \\
21.1 \\
23.4 \\
\hdashline\end{array}$ & $\begin{array}{l}13.7 \\
16.8 \\
14.8 \\
12.2\end{array}$ & - \\
\hline July 11 & $\begin{array}{r}6 \\
12 \\
24 \\
36\end{array}$ & 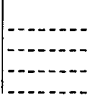 & 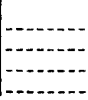 & 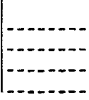 & $-\cdots$ & 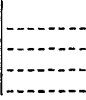 & 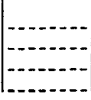 & $\begin{array}{l}18.7 \\
19.7 \\
30.6 \\
26.7\end{array}$ \\
\hline
\end{tabular}


WATER SPREADING IN BOX CREEK BASIN, WYOMING A-45

Soil-moisture observations-Continued

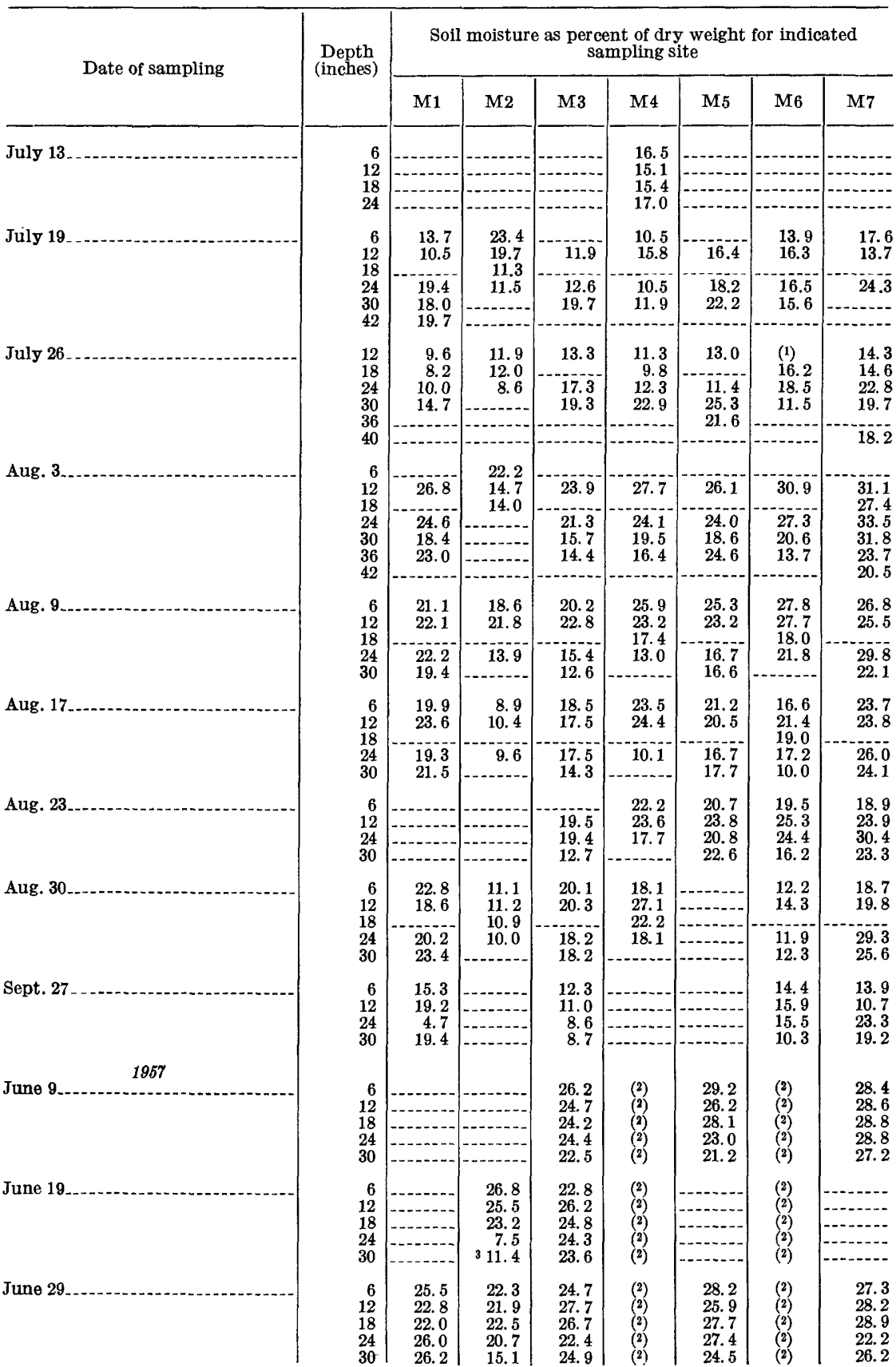


Soil-moisture observations-Continued

\begin{tabular}{|c|c|c|c|c|c|c|c|c|}
\hline \multirow{2}{*}{ Date of sampling } & \multirow{2}{*}{$\begin{array}{c}\text { Depth } \\
\text { (inches) }\end{array}$} & \multicolumn{7}{|c|}{$\begin{array}{l}\text { Soil moisture as percent of dry weight for indicated } \\
\text { sampling site }\end{array}$} \\
\hline & & M1 & M2 & M3 & M4 & M5 & M6 & M7 \\
\hline July 3. & $\begin{array}{r}6 \\
12 \\
18 \\
24 \\
30\end{array}$ & $\begin{array}{l}27.0 \\
28.6 \\
26.4 \\
26.2\end{array}$ & $\begin{array}{l}21.4 \\
18.5 \\
20.8 \\
16.2 \\
11.0\end{array}$ & $\begin{array}{l}27.0 \\
28.9 \\
27.5 \\
25.2 \\
25.4\end{array}$ & $\begin{array}{l}(2) \\
(2) \\
(2) \\
(2) \\
(2)\end{array}$ & $\begin{array}{l}27.6 \\
25.6 \\
27.6 \\
26.2 \\
26.4\end{array}$ & $\begin{array}{l}(2) \\
(2) \\
(2) \\
(2) \\
(2)\end{array}$ & $\begin{array}{l}28.7 \\
22.6 \\
24.9 \\
26.6 \\
29.3\end{array}$ \\
\hline July $10 \ldots$ & $\begin{array}{r}6 \\
12 \\
18 \\
24 \\
30\end{array}$ & $\begin{array}{l}20.4 \\
22.4 \\
26.2 \\
27.2 \\
22.1\end{array}$ & \begin{tabular}{|c|}
-1 \\
\hdashline-1 \\
\hdashline$-\cdots$
\end{tabular} & $\begin{array}{l}23.6 \\
23.9 \\
24.2 \\
25.2 \\
22.7\end{array}$ & $\begin{array}{l}(2) \\
(2) \\
(2) \\
(2) \\
(2)\end{array}$ & $\begin{array}{l}27.2 \\
26.3 \\
26.0 \\
25.9 \\
26.4\end{array}$ & $\begin{array}{r}29.6 \\
28.0 \\
27.0 \\
\end{array}$ & $\begin{array}{l}21.9 \\
23.3 \\
23.2 \\
25.3 \\
26.3\end{array}$ \\
\hline July $24 \ldots$ & $\begin{array}{r}6 \\
12 \\
18 \\
24 \\
30\end{array}$ & $\begin{array}{l}26.9 \\
22.5 \\
25.3 \\
25.5 \\
28.2\end{array}$ & $\begin{array}{l}20.9 \\
17.3 \\
17.6 \\
15.6 \\
17.3\end{array}$ & $\begin{array}{l}23.8 \\
25.8 \\
25.6 \\
26.4 \\
24.4\end{array}$ & $\begin{array}{l}27.7 \\
27.9 \\
25.6 \\
21.5 \\
20.9\end{array}$ & $\begin{array}{l}25.6 \\
27.5 \\
28.7 \\
25.8 \\
25.7\end{array}$ & 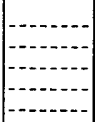 & $\begin{array}{l}28.1 \\
24.7 \\
27.3 \\
24.8 \\
29.5\end{array}$ \\
\hline Aug. 1 . & $\begin{array}{r}6 \\
12 \\
18 \\
24 \\
30\end{array}$ & $\begin{array}{l}28.1 \\
23.1 \\
23.8 \\
22.2 \\
27.5\end{array}$ & $\begin{array}{l}18.5 \\
17.4 \\
10.6 \\
14.8 \\
22.4\end{array}$ & $\begin{array}{l}22.6 \\
22.7 \\
23.4 \\
23.8 \\
21.4\end{array}$ & $\begin{array}{l}22.0 \\
21.2 \\
24.2 \\
18.0 \\
10.4\end{array}$ & $\begin{array}{l}24.5 \\
25.6 \\
21.8 \\
21.8 \\
25.1\end{array}$ & $\begin{array}{l}24.9 \\
28.0 \\
26.1 \\
26.9 \\
28.9\end{array}$ & $\begin{array}{l}20.7 \\
20.8 \\
17.8 \\
17.5 \\
14.5\end{array}$ \\
\hline Aug. 14.... & $\begin{array}{r}6 \\
12 \\
18 \\
24 \\
30\end{array}$ & $\begin{array}{l}17.6 \\
22.9 \\
22.8 \\
21.6 \\
21.0\end{array}$ & $\begin{array}{r}11.4 \\
10.4 \\
11.1 \\
9.7 \\
8.7\end{array}$ & $\begin{array}{l}19.1 \\
22.9 \\
23.5 \\
21.9 \\
24.0\end{array}$ & $\begin{array}{l}21.0 \\
18.1 \\
21.5 \\
20.7 \\
22.3\end{array}$ & $\begin{array}{l}23.9 \\
23.2 \\
24.3 \\
27.4 \\
21.7\end{array}$ & $\begin{array}{l}16.7 \\
23.8 \\
24.1 \\
28.5 \\
27.7\end{array}$ & $\begin{array}{l}12.6 \\
13.8 \\
17.8 \\
19.2 \\
25.5\end{array}$ \\
\hline Aug. 21... & $\begin{array}{r}6 \\
12 \\
18 \\
24 \\
30\end{array}$ & $\begin{array}{l}14.5 \\
14.9 \\
16.1 \\
18.0 \\
17.6\end{array}$ & 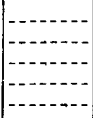 & $\begin{array}{l}22.4 \\
23.6 \\
23.6 \\
22.3 \\
19.7\end{array}$ & $\mid$\begin{tabular}{l}
-1 \\
\hdashline-1
\end{tabular} & $\begin{array}{l}22.0 \\
27.4 \\
25.9 \\
21.6 \\
26.2\end{array}$ & $\begin{array}{l}17.1 \\
25.3 \\
27.6 \\
31.0 \\
30.3\end{array}$ & $\begin{array}{l}16.0 \\
13.4 \\
17.4 \\
18.3 \\
20.1\end{array}$ \\
\hline Aug. $29 \ldots$ & $\begin{array}{r}6 \\
12 \\
18 \\
24 \\
30\end{array}$ & $\begin{array}{l}16.3 \\
21.0 \\
25.4 \\
21.7 \\
25.4\end{array}$ & | & $\begin{array}{l}17.7 \\
20.6 \\
18.6 \\
17.3 \\
23.2\end{array}$ & $\mid \begin{array}{l}-1 \\
-1\end{array}$ & $\begin{array}{l}21.6 \\
19.4 \\
24.0 \\
21.9 \\
23.8\end{array}$ & $\begin{array}{l}19.9 \\
23.8 \\
27.7 \\
30.4 \\
29.7\end{array}$ & $\begin{array}{l}16.9 \\
19.0 \\
17.2 \\
15.6 \\
25.9\end{array}$ \\
\hline Sept. 12 & $\begin{array}{r}6 \\
12 \\
18 \\
24 \\
30\end{array}$ & $\begin{array}{l}12.8 \\
15.1 \\
19.3 \\
20.5 \\
27.2\end{array}$ & $\mid$\begin{tabular}{l}
-1 \\
\hdashline-1
\end{tabular} & $\begin{array}{l}11.1 \\
11.0 \\
15.4 \\
22.0 \\
22.4\end{array}$ & מי & $\begin{array}{l}21.1 \\
24.2 \\
26.5 \\
23.8 \\
24.2\end{array}$ & $\begin{array}{l}18.2 \\
21.2 \\
26.0 \\
23.2 \\
31.1\end{array}$ & 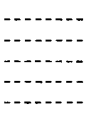 \\
\hline Sept. $19 \ldots$. & $\begin{array}{r}6 \\
12 \\
18 \\
24 \\
30\end{array}$ & $\begin{array}{l}25.0 \\
24.8 \\
27.5 \\
-.-2 \\
-.-\end{array}$ & \begin{tabular}{r}
19.5 \\
13.1 \\
10.0 \\
\hdashline \\
\end{tabular} & $\begin{array}{l}26.8 \\
24.1 \\
25.6 \\
22.8 \\
-.-. .\end{array}$ & 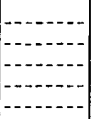 & $\begin{array}{r}26.2 \\
25.4 \\
25.9 \\
25.6 \\
-.--\end{array}$ & $\begin{array}{c}27.0 \\
25.9 \\
28.2 \\
27.8 \\
-\cdots\end{array}$ & $\begin{array}{l}23.8 \\
22.8 \\
22.9 \\
23.5 \\
20.9\end{array}$ \\
\hline Oct. $2 \ldots$ & $\begin{array}{r}6 \\
12 \\
18 \\
24 \\
30\end{array}$ & $\begin{array}{l}21.6 \\
19.1 \\
24.7 \\
23.0 \\
17.9\end{array}$ & $\mid$\begin{tabular}{l}
-1 \\
\hdashline-1
\end{tabular} & $\begin{array}{l}17.8 \\
23.5 \\
23.9 \\
22.8 \\
22.2\end{array}$ & 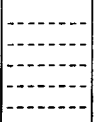 & $\begin{array}{l}26.3 \\
25.8 \\
26.4 \\
27.4 \\
25.1\end{array}$ & $\begin{array}{l}26.6 \\
27.6 \\
26.4 \\
30.1 \\
29.8\end{array}$ & $\begin{array}{l}25.7 \\
24.3 \\
22.4 \\
25.2 \\
22.0\end{array}$ \\
\hline Nov. $13 \ldots$ & $\begin{array}{r}6 \\
12 \\
18 \\
24 \\
30\end{array}$ & $\begin{array}{l}26.4 \\
21.6 \\
28.0 \\
25.8 \\
23.5\end{array}$ & 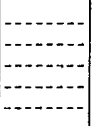 & $\begin{array}{l}22.5 \\
24.3 \\
23.8 \\
26.0 \\
24.3\end{array}$ & 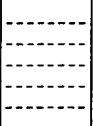 & $\begin{array}{l}27.0 \\
27.1 \\
25.7 \\
23.2 \\
22.3\end{array}$ & $\begin{array}{l}23.8 \\
17.7 \\
12.6 \\
11.1 \\
12.7\end{array}$ & $\begin{array}{r}27.5 \\
22.9 \\
22.5 \\
21.4 \\
----\end{array}$ \\
\hline
\end{tabular}

1 Dry.

2 Flooded.

39.8 percent at 36-inch depth, site M2 on June 19, 1957. 


\section{REFERENCES CITED}

Bradfield, R. and Jamison, V. C., 1938, Soil structure . . Attempts at its quantitative characterization: Soil Sci. Soc. America Proc., v. 3, p. 70-76.

Culler, R. C., 1961, Hydrology of Upper Cheyenne River basin: U.S. Geol. Survey Water-Supply Paper 1531-A.

Gardner, Robert, 1937, A method of measuring the capillary tension of soil moisture over a wide moisture range: Soil Sci., v. 43, p. 277-283.

Hadley, R. F. and Schumm, S. A., 1961, Hydrology of Upper Cheyenne River basin: U.S. Geol. Survey Water-Supply Paper 1531-B.

Kennon, F. W. and Peteron, H. V., 1960, Hydrology of Cornfield Wash, New Mexico: U.S. Geol. Survey Water-Supply Paper 1475-B, p. 87.

Lyon, T. L., Buckman, H. O., and Brady, N. C., 1952, The nature and properties of soils: New York, The Macmillan Co., p. 190.

U.S. Geological Survey, 1958, Surface water supply of the United States, 1957, pt. 6-A, Missouri River basin above Sioux City, Iowa: U.S. Geol. Survey Water-Supply Paper 1509, 454 p.

U.S. Weather Bureau, 1949-57, Climatological data, Wyoming. 


\section{INDEX}

\begin{tabular}{|c|c|}
\hline Page & Page \\
\hline Abstract................ & Precipitation, analysis of data. .... \\
\hline 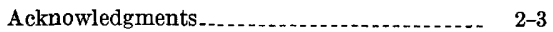 & data \\
\hline Agriculture & largest daily \\
\hline Angostura Reservoir, sediment reduction & measurements. \\
\hline & Procedures............. \\
\hline Bibliography & Purpose and scope of study \\
\hline Box Creek at mouth, streamflow data. ...... & \\
\hline suspended-sediment measurements ....... 34-38 & Reservoirs, description and runoff - \\
\hline Box Creek near Bill, streamflow data........ & Runoff, data. $\ldots$ \\
\hline suspended-sediment measurements. & $\begin{array}{l}\text { disposition. } \\
\text { map }\end{array}$ \\
\hline Conclusions . . . . & measurements. 7 \\
\hline Dikes. See & Sedimentation, measurements._... 8-9, 32 \\
\hline data & ranges.................. \\
\hline Dull Center, precipitation data........ & 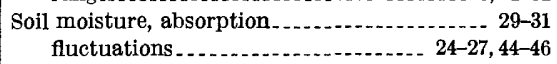 \\
\hline Field capacity, definition. & limits \\
\hline (2.2. & retention data...... 28,29 \\
\hline Fort Union formation & $\begin{array}{lr}\text { retention relationships } & \\
\text { trends. } & 28\end{array}$ \\
\hline Ground-water levels, fluctuation & $\begin{array}{l}\text { use in water spreader. } \\
\text { Spreader dikes. See Water-spreading system. }\end{array}$ \\
\hline Hydrographs.... & $\begin{array}{l}\text { Storage capacity, definition } \\
\text { Streamflow, computations based on records.. } \\
17-23\end{array}$ \\
\hline $9,18,20$ & data. $15-16$ \\
\hline Instrumentation & Suspended-sediment measurements \\
\hline Introduc & \\
\hline Investigation, methods....... & $\begin{array}{l}\text { U.S. Weather Bureau gage Bill } 14 \text { SE., loca- } \\
\text { tion. }\end{array}$ \\
\hline Location. . & Vegetation, effect. \\
\hline Moisture-retention curve, definition ........... & Wasatch formation \\
\hline Observation wells. .... $7-8,23,24$ & $\begin{array}{l}\text { Water-spreader system, sedimentation } \\
\text { soil-moisture fluctuation }\end{array}$ \\
\hline tage, definition...... & $\begin{array}{l}\text { soil-moisture retention } \\
\text { streamflow data. }\end{array}$ \\
\hline ermanent-wilting point... & description \\
\hline avsiography & ells See 0 \\
\hline
\end{tabular}

A-48 